\title{
Delitos Tributarios como Actos Criminales previos al Delito de Lavado de Activos
}

Tax Crimes as Criminal Acts previous to the Crime of Money Laundering

\author{
Dr. Fidel Nicolás Mendoza Llamacponcca, PhD \\ Investigador Jurídico, USIL y profesor Universitario
}

Artículo Original (Investigación)

RFJ, No. 3, 2018, pp. 255-296, ISSN 2588-0837

RESUMEN: a nivel de los países latinoamericanos, se ha dado relevancia al carácter de "delito previo" de los delitos tributarios, constituyendo uno de los principales actos delictivos que dan base al lavado. En ese sentido, el presente documento explora las implicancias (debilidades a ser superadas) de este contexto específico para el desarrollo y fortalecimiento del sistema jurídico penal.

PALABRAS CLAVE: delitos tributarios, actos criminales, lavado de activos, derecho penal, "soft law".

ABSTRACT: for Latin American countries, the character of a "prior crimes" of tax crimes has become relevant, representing one of the main criminal acts that provide the basis for money laundering. This document explores the implications (weaknesses to be overcome) of this specific legal scenario for the development and strengthening of the criminal justice system.

KEY WORDS: tax crime, criminal action, money laundering, criminal law, soft law

\section{INTRODUCCIÓN}

En la versión del 2003 de las recomendaciones del Grupo de Acción Financiera Internacional (GAFI), de modo similar a la reformulada el 2012, el GAFI propuso a los Estados incluir la más "amplia gama" de delitos subyacentes que puedan dar base al blanqueo de bienes. Esta 
institución publicó sus recomendaciones revisadas el 16/Feb/2012, bajo el título "Estándares internacionales sobre la lucha contra el lavado de activos, el financiamiento del terrorismo y la proliferación" ${ }^{203}$. Entre los aspectos novedosos de la revisión de las recomendaciones del GAFI de 2012 , se tiene la incorporación por vez primera de los delitos tributarios como hechos delictivos precedentes susceptibles de constituirse en delito fuente del lavado de activos ${ }^{204}-$. En el ámbito internacional, dicha disposición carece de precedente expreso en las Convenciones de las Naciones Unidas sobre la materia -en estas normas de hard law únicamente se había establecido que los Estados debían asegurar que el delito de lavado sea tipificado, en sus legislaciones, abarcando la "más amplia gama posible" de delitos fuente-.

Las recomendaciones del GAFI constituyen disposiciones de soft law, por tanto, no obligatorias, desde la perspectiva jurídica -como sí lo son las Convenciones internacionales o hard law-. No obstante, sus estándares antilavado y procedimientos de seguimiento o evaluaciones mutuas en sus países miembros, tienen de facto un poder político que resulta ineludible. La comunidad internacional, con relaciones de cooperación estrechas y supervisadas, se encuentra vinculada políticamente a objetivos comunes, entre ellos, la lucha contra el lavado de activos y la financiación del terrorismo o de la proliferación de armas de destrucción masiva. En tal sentido, la institución más importante en el seguimiento político internacional del nivel de cumplimiento de estos estándares internacionales, sin duda, lo es el GAFI. A tal punto que se encuentra premunido de facultades para calificar a los países que no ajusten sus legislaciones a los estándares que ha establecido, como países deficientes en el control antilavado o, incluso, como países no cooperantes (conformando las denominadas "listas grises" o "listas negras") 205.

El debate relativo a la incorporación de los delitos tributarios como delitos fuente en la Recomendaciones del GAFI, es oportuno precisar, fue decidido como consecuencia de la reunión plenaria de esta institución

203 En:http://www.fatf-gafi.org/media/fatf/documents/recommendations/pdfs/FATF-40-Rec-2012-Spanish.pdf.

204 Cassani, U. (2013), L'infraction fiscale comme crime sous-jacent au blanchiment d'argent: considérations de lege ferenda, en RSDAMF, Vol. 85, № 2, Zürich, Schulthess Verlag. 18.

205 Durrieu Figueroa, R. (2013), El delito tributario y el lavado de activos, en Alterini, J. (dir.), La Ley, Año LXXVII, Nº 87, 14 de mayo, Buenos Aires. 1. 
realizada en octubre de 2009. Para aquella data los estándares vinculados al lavado de activos habían sido reformulados el 2003, mientras que los relativos al financiamiento del terrorismo lo fueron el 2008. En tal sentido, en el plenario de 2009, el GAFI acordó una lista de temas a ser considerados en la preparación de la cuarta ronda de evaluaciones mutuas que se desarrollaría en dos fases, durante un período de dos años ${ }^{206}$.

La primera fase ${ }^{207}$ de la discusión dirigida a la revisión de los estándares internacionales del GAFI incluyó fundamentalmente la siguiente temática: el enfoque basado en el riesgo y su vinculación con las Recomendaciones 1 (particularmente, los delitos tributarios como delitos susceptibles de dar base al lavado de activos), 5 (medidas de diligencia debida relativas al cliente), 6 (personas expuestas políticamente) y la 9 (la delegación -por parte de las instituciones financieras- de deberes de identificación y conocimiento del cliente a favor de terceros intermediarios). El documento emitido como consecuencia de esta primera fase de discusiones, precisa Blanco Cordero ${ }^{208}$, fue sometido a consulta pública hasta enero de 2011.

La segunda fase ${ }^{209}$ se llevó a cabo entre octubre de 2010 y junio de 2011, examinándose, entre otros aspectos, los siguientes: el enfoque basado en el riesgo en materia de supervisión, la propiedad efectiva de activos o titularidad real, incluyendo las Recomendaciones 5 (procedimientos de diligencia debida), 33 (medidas de transparencia de las personas jurídicas) y 34 (medidas de transparencia de estructuras jurídicas como los fideicomisos), las personas expuestas políticamente, la protección de datos y privacidad. Así también, la cooperación internacional en el contexto de la Recomendación 40 (medidas complementación de ayuda y colaboración intergubernamental) y la apli-

206 Financial Action Task Force (2010), Consultation Paper. The Review of the Standards - Preparation for the 4th Round of Mutual Evaluations, October 2010, GAFI/ OECD. 3. Disponible en: http://www.fatf-gafi.org/media/fatf/documents/publicconsultation/First\%20public\%20consultation\%20document.pdf.

207 Financial Action Task Force (2011), Consultation Paper. The Review of the Standards - Preparation for the 4th Round of Mutual Evaluations. Second public consultation, June 2011, GAFI/OECD. 4. Disponible en: http://www.fatf-gafi.org/media/fatf/documents/publicconsultation/Second\%20public\%20consultation\%20document.pdf.

208 Blanco Cordero, I. (2015), El delito de blanqueo de capitales, $5^{\text {a }}$ ed., Navarra, Aranzadi. 468.

209 Financial Action Task Force (2011), Consultation Paper.... 4. 
cación adecuada o inadecuada de las Recomendaciones del GAFI y el rol de las Unidades de Inteligencia Financiera.

El debate actual, acerca de la incorporación de los delitos tributarios como delitos fuente del blanqueo - de acuerdo con las recomendaciones del GAFI actualizadas al 2012-, como suele ocurrir con las disposiciones del soft law así de relevantes, ha tenido influencia en instituciones intergubernamentales como la Unión Europea. Así, el Parlamento y Consejo de la Unión han emitido el más reciente instrumento europeo en materia de prevención antiblanqueo: la Directiva (UE) 2015/849, del 20/May/2015 (relativa a la prevención de la utilización del sistema financiero para el blanqueo o la financiación del terrorismo -documento que modifica el Reglamento [UE] No 648/2012 del Parlamento Europeo y del Consejo, y deroga las Directivas 2005/60/CE del Parlamento Europeo y del Consejo y 2006/70/CE de la Comisión-). En el apartado 11 de la Exposición de Motivos de la Directiva se señala que "es importante destacar expresamente que los «delitos fiscales» relacionados con los impuestos directos e indirectos están incluidos en la definición de «actividad delictiva» en sentido amplio con arreglo a la presente Directiva, de conformidad con las Recomendaciones revisadas del GAFI".

Por su parte, el Grupo de Acción Financiera de Latinoamérica (GAFILAT) ${ }^{210}$, mediante el reciente Informe de diciembre de 2015 -en atención de las recomendaciones del GAFI actualizadas a 2012-, realizó un Estudio sobre las amenazas en materia de lavado de activos en Latinoamérica. Con respecto a la subregión andina (que agrupa al Perú junto con Colombia, Bolivia, Chile y Ecuador), identificó que los principales delitos fuente lo constituían el narcotráfico, la corrupción, los delitos fiscales -aunque no reprimible en algunos de dichos paí-

210 El Grupo de Acción Financiera de Latinoamérica (GAFILAT) es una organización intergubernamental de base regional que agrupa a 16 países de América del Sur, Centroamérica y América de Norte para combatir el lavado de dinero y la financiación del terrorismo. Su creación data del 08/Dic/2000 en Cartagena de Indias (Colombia), por parte de los representantes de los gobiernos de 9 países: Argentina, Bolivia, Brasil, Chile, Colombia, Ecuador, Paraguay, Perú y Uruguay. Con posterioridad se incorporaron 7 países como miembros: México (2006), Costa Rica, Panamá (2010), Cuba (2012), Guatemala, Honduras y Nicaragua (2013). Destacan como observadores de dicha institución Alemania, el Banco Centroamericano de Integración Económica, el Grupo Asia-Pacífico contra el Lavado de Activos, INTERPOL, la Oficina de las Naciones Unidas contra la Droga y el Delito, y Portugal y la OEA. 
ses- y los delitos ambientales (principalmente, la minería ilegal) ${ }^{211}$. Por tanto, a nivel de los países latinoamericanos, se ha dado relevancia al carácter de delito previo de los delitos tributarios, constituyendo según identifica el Informe de GAFILAT- uno de los principales actos delictivos que dan base al lavado.

\section{PROBLEMÁTICA LEGISLATIVA}

\subsection{Derecho comparado}

El Derecho comparado confirma que son varios los sistemas jurídicos que han incorporado a determinados delitos tributarios como delitos fuente del lavado de activos. Al respecto, identifica Díaz y García Conlledo ${ }^{212}$, la tendencia internacional parece apuntar hacia la incorporación de estas modalidades delictivas como delito precedente apartir de diversos matices. Por regla general, su consideración de delito fuente dependerá que los delitos tributarios presenten características de gravedad o vínculos con el crimen organizado. Sin perderse de vista que, según hemos identificado, existen algunos sistemas jurídicos donde en apariencia sus leyes penales abarcarían al íntegro de los delitos fiscales como delitos subyacentes al lavado -razón por la cual algunos intérpretes proponen criterios de restricción a la aparente admisión integral de los delitos fiscales como delitos previos, recomendando su aceptación solo limitada a algunos de estos-.

En algunas legislaciones, los delitos tributarios únicamente de carácter grave ${ }^{213}$ han sido expresamente establecidos en los preceptos sobre el delito previo, tal como sucede en Alemania (§ 261, apartado

211 Informe del GAFILAT denominado "Análisis de amenazas regionales en materia de lavado de activos”, de Dic/2015. Disponible en: http://www.gafilat.org/UserFiles/ documentos/es/AnalisisAmenazasGAFILAT.pdf.

212 Díaz y García Conlledo, M. (2014), ¿Puede el delito de defraudación tributaria constituir actividad delictiva previa a efectos del blanqueo?, en Demetrio Crespo, Eduardo (dir.) / Maroto Calatayud, Manuel (coord.), Crisis financiera y derecho penal económico, Montevideo, BdF. 614.

213 Blanco Cordero, I. (2015), El delito de blanqueo.... 493. 
1, núm. $3^{214}$, del StGB), Suiza (art. $305^{\text {bis }}$, apartado $1^{215}$, del CP) y Bél-

214 CP alemán, § 261, frase 1, núm. 3 (Blanqueo de capitales, ocultación de elementos patrimoniales adquiridos ilegalmente): “1) Quien esconda u oculte el origen de un bien procedente de uno de los hechos delictivos descritos en la frase 2 siguiente, o quien impida u obstaculice la investigación del origen, la localización, incautación, confiscación o constitución de garantías sobre tal bien, será sancionado con una pena de privación de libertad de entre 3 meses y 5 años. [Traducción de Martínez Egaña, D. (2011), "El delito fiscal y el delito de blanqueo de capitales en Alemania”, en CT, No 141, Madrid, IEF. 174175]. En consecuencia, se aprecia que el CP alemán (§ 261, frase 1, núm. 3) incorpora como delitos susceptibles de dar lugar al lavado de activos a determinados delitos fiscales previstos en el Código Tributario, tales como el § 373 (contrabando efectuado de forma profesional) y el $\S 374$ (receptación fiscal de mercancías). Conforme sostiene Isidoro Blanco, "la norma penal alemana concreta mucho más la cuestión, y advierte en el último párrafo del $n^{0} 1 \S 261$ StGB que «El primer párrafo se aplicará en los casos de defraudación fiscal cometidos profesionalmente o de forma organizada (en banda), según el § 370 del Código tributario, respecto a los gastos ahorrados por la defraudación fiscal y las compensaciones y devoluciones de impuestos obtenidas indebidamente, así como en los casos del segundo inciso del párrafo 3 , también respecto de los bienes por los que se hayan defraudado impuestos»", Cfr. Blanco Cordero, I. (2015), El delito de blanqueo.... 498. Dicho análisis es también razonado por el Tribunal Supremo en la STS No 974/2012 (del 05/Dic/2012, FJ 37º-2 ${ }^{\circ}-\mathrm{C}$, Ponente: Berdugo Gómez de la Torre. Caso «Ballena Blanca»). Para un estudio sobre el delito tributario previo y su problemática en Alemania, Ambos, K. (2015), "La defraudación tributaria como hecho previo del lavado de dinero en Alemania”, en Ambos, K. / Caro Coria, C. / Malarino, E. (dir.), Lavado de activos y compliance, Lima, Jurista Editores, 293-294. Considerando que los únicos delitos tributarios idóneos para calificar como hecho delictivo previo son la obtención indebida de devoluciones y de crédito fiscal, Cfr. Tiedemann, K. (2010), Manual de derecho penal económico. Parte general y especial, Valencia, Tirant lo Blanch. 345-346.

215 CP suizo, art. 305bis (Blanchiment d'argent): "1) Aquel que haya cometido un acto dirigido a dificultar la identificación del origen, el descubrimiento o la confiscación de valores patrimoniales (activos), sobre los cuales sabía o debía presumir que procedían de un crimen o de un delito fiscal agravado, será reprimido con pena privativa de libertad no menor de 3 años o con una pena pecuniaria" (Traducción libre). El CP suizo fue modificado por la Ley Federal del 12/Dic/2014, Ley mediante la cual se implementaron las Recomendaciones del GAFI revisadas en 2012. En lo que atañe al delito de lavado de activos, la modificación del art. $305^{\text {bis }}$, apartado 1, entró en vigencia el 01/ Ene/2016. De acuerdo con lo precisado por Úrsula Cassani, desde que el art. $305^{\text {bis }}$ fue puesto en vigor (el 01/Ago/1990), la represión del lavado de activos se limitaba únicamente a los valores patrimoniales nacidos del "crimen", no así los procedentes del "delito" (en esta diferenciación con base en la gravedad de las penas, los crímenes 
gica (art. 505, sétimo párrafo ${ }^{216}$, del CP). En similar sentido, en Chile por disposición legal (art. 27, lit. $\mathrm{a}^{217}$, de la Ley $\mathrm{N}^{\circ}$ 19.913, actualizada por la Ley $\mathrm{N}^{\circ} 20.818$ ), se incorporó al delito de obtención fraudulenta de devoluciones de impuesto (previsto en el art. 97, $\mathrm{N}^{\circ} 4$, tercer párrafo $^{218}$, del Código Tributario) como delito fuente del lavado, mas no

son reprimidos con penas privativas de libertad superiores a tres años, mientras que los delitos lo son por debajo de dicha penalidad). En el Anteproyecto formulado por el Consejo Federal, que fue aprobada por la reseñada Ley Federal (del 12/Dic/2014), se propuso ampliar el texto del art. $301^{\text {bis }}$, apartado 1 , del CP suizo con el fin de incorporar como objeto del lavado tanto a los activos "proveniente(s) de un crimen", como aquellos que provengan de "un delito fiscal cualificado". A su vez, en el apartado 1bis, el legislador suizo concreta la amplitud de dicho delito fuente de procedencia tributaria, disponiendo que serán considerados como "delito fiscal cualificado", las infracciones previstas en el art. 186 de la Ley Federal sobre el Impuesto Federal Directo, y en el art. 59, apartado 1, primer párrafo, de la Ley Federal sobre la Armonización de los Impuestos Directos de los Cantones y Municipios (ambas normas, del 14/Dic/1990), siempre que los impuestos deducidos por período fiscal asciendan a más de CHF 300,000 francos suizos. Para más detalles, Cfr. Cassani, U. (2015), "L’extension du système de lutte contre le blanchiment d'argent aux infractions fiscales: Much Ado About (Almost) Nothing”, en RSDAMF, Vol. 87, N² 2, Zürich, Schulthess Verlag. 80.

216 CP belga, art. 505, sétimo párrafo: "Será reprimido con prisión de 15 días a 5 años y multa de $€ 26$ a $€ 100,000$ o una de estas penas: [...] Salvo en el caso del autor, coautor o cómplice del delito de donde provienen las cosas mencionadas en el art. $42^{\circ}$ 3, los delitos citados en el apartado 1, 2 y 4, se refieren exclusivamente, en materia tributaria, a los actos cometidos en un contexto de fraude fiscal grave, organizado o no" (Traducción libre). Sobre esta cuestión, Delrue, G. (2014), Le blanchiment de capitaux et le financement du terrorisme, 2ème éd., Anvers, Malku Uitgevers. 109; Fernandez-Bertier, M. / Lecocq, A. (2015), "La Belgique face à la lutte contre le blanchiment de capitaux et le financement du terrorismo: 4e rapport d'évaluation mutuelle par le GAFI", en ReDPC, $N^{0} 7-8$, Bruxelles, Palais de Justice - La Charte. 767.

217 Ley chilena No 19.913 (actualizada por Ley No 20.818), art. 27, lit. a: "Será castigado con presidio mayor en sus grados mínimo a medio y multa de 200 a 1,000 unidades tributarias mensuales: a) El que de cualquier forma oculte o disimule el origen ilícito de determinados bienes, a sabiendas de que provienen, directa o indirectamente, de la perpetración de hechos constitutivos de alguno de los delitos contemplados [...] en el párrafo tercero del número $4^{\circ}$ del artículo 97 del Código Tributario".

218 Código Tributario chileno (Decreto Ley No 830), art. 97, núm. 4: "Las siguientes infracciones a las disposiciones tributarias serán sancionadas en la forma que a continuación se indica: Las siguientes infracciones a las disposiciones tributarias serán sancionadas en la forma que a continuación se indica: [...] $4^{\circ}$.- [...] (párrafo tercero) El que, 
así el delito de defraudación fiscal -o elusión fraudulenta del pago de tributos-. Finalmente-según hemos referido-, en otros ordenamientos las disposiciones legales parecieren contemplar sin mayores distinciones a los delitos tributarios de defraudación como delitos fuente, cual es el caso de Portugal que incorpora genéricamente al "fraude fiscal" como actividad criminal previa (art. 368-A, inc. 1219, del CP). Situación similar, aunque evidentemente con un mayor ámbito de alcance, ocurriría en el Perú al establecerse -dentro de las actividades criminales previstas como delito previo (art. 10, segundo párrafo del DLeg No 1106) - que los "delitos tributarios" pueden dar base al delito de lavado.]Debemos, sin embargo, precisar que otros ordenamientos jurídicos no han hecho alusión explícita a los delitos tributarios como delitos precedentes. Antes bien sus intérpretes - desde diversos sectores de la doctrina y jurisprudencia- han considerado que la idoneidad de los delitos fiscales (para constituirse en delito subyacente) puede desprenderse de la propia estructura típica de sus regulaciones penales, tomando como base su no explícita exclusión. Tal es el caso del elemento "producto directo o indirecto de un crimen o de un delito" previsto en el CP de Francia (art. 324-1220), conforme al criterio compartido por Tricot y Binet-Grosclaude ${ }^{221}$ y por la Sentencia de Casación No 07-82977 de la Sala Penal del Tribunal Supremo Francés ${ }^{222}$ Por su

simulando una operación tributaria o mediante cualquiera otra maniobra fraudulenta, obtuviere devoluciones de impuesto que no le correspondan, será sancionado con la pena de presidio menor en su grado máximo a presidio mayor en su grado medio y con multa del 100\% al 400\% de lo defraudado".

219 CP portugués, art. 368-A, apartado 1 (Branqueamento): "1 $1^{\circ}$.- A los efectos de lo dispuesto en los siguientes números, se consideran activos o bienes procedentes de la práctica, bajo cualquier forma de participación, de los actos típicos de proxenetismo [...] fraude fiscal [...]" (Traducción libre).

220 CP francés, art. 324-1 (Blanchiment): "Constituye delito de blanqueo facilitar, por cualquier medio, una justificación falsa acerca del origen de los bienes o ingresos del autor de un crimen o de un delito, cuando le haya reportado al autor un provecho directo o indirecto. También constituye delito de blanqueo el hecho de colaborar en una operación de inversión, de encubrimiento o de conversión del producto directo o indirecto de un crimen o delito". Traduc. de Aránguez Sánchez, C. / Alarcón Navío, E. (2003), El Código penal francés. Traducido y anotado, Granada, Comares. 181.

221 Tricot, J. / Binet-Grosclaude, A. (2013), La lutte contre le blanchiment en France, en Cesoni, M. L. (dir.)

222 Sentencia de Casación No 07-82977 (del 20/Feb/2008), emitida por la Sala Penal del Tribunal de Casación de Francia. Casación dirigida contra la resolución condenatoria emitida por el Tribunal de Apelación de Aix-en-Provence (del 28/Mar/2007). 
parte, en Italia, tal planteamiento es similarmente seguido por Buratti y Campana ${ }^{223}$, con respecto al elemento típico "dinero, bienes u otros beneficios procedentes del delito doloso" previsto en su CP (art. 648-bisis2). Sobre esta cuestión, estos autores sostienen que con la modificación del art. 648-bis, efectuada por la Ley No 328/1993 (del 09/Ago/1993), el legislador italiano abandonó el criterio del numerus clausus en la determinación legal del delito previo. Por lo que, a partir del sistema amplio vigente en el CP de dicho Estado, todos los delitos dolosos pueden dar lugar al lavado de activos. Esta consideración ha sida confirmada por el Tribunal Supremo Italiano en múltiples resoluciones, particularmente en la Sentencia No 6061/2012. Conforme precisa la citada Casación, "únicamente se encuentran excluidos del ámbito de aplicación del art. 608-bis, las contravenciones y los delitos imprudentes; por tanto, todos los delitos dolosos, inclusive los delitos de fraude fiscal, son idóneos para constituirse en delito previo" ${ }^{225}$.

De modo similar, el legislador de Argentina alude al origen de los "bienes provenientes de un ilícito penal" (art. $303^{226} \mathrm{del} \mathrm{CP).} \mathrm{Mientras} \mathrm{que,}$ en el caso de Brasil, la normativa penal hace referencia a los activos procedentes de la "infracción penal" (art. 1 de la Ley $\mathrm{N}^{\circ}$ 9.613 227 , modi-

Disponible en: https://www.legifrance.gouv.fr/affichJuriJudi.do?oldAction=rechJuriJudi\&idTexte=JURITEXT000018338279\&fastReqId=748356780\&fastPos $=1$.

223 Buratti, B. / Campana, G. (2012), Contrasto al riciclaggio e misure anti evasione. Le nuove limitazioni alla circolazione dei capitali, San Marino, Maggioli Editore. 51.

224 CP italiano, art. 648-bis (Riciclaggio): "Fuera de los casos de concurso en el delito, aquel que sustituye o trasfiere dinero, bienes $u$ otros beneficios procedentes del delito doloso, o efectúa con relación a estos otras operaciones, a fin de obstaculizar la identificación de su procedencia delictiva, será reprimido con pena de prisión de 4 a 12 años y con multa de $€ 5,000$ a $€ 25,000$ (Traducción libre).

225 Sentencia de Casación $N^{\circ}$ 6061/2012 (del 17/Ene/2012, FJ 3), emitida por la Sección Segunda de la Sala Penal del Tribunal Supremo de Italia. Disponible en: http:// www.italgiure.giustizia.it/xway/application/nif/clean/hc.dll?verbo=attach\&db=snpen\&id=./20120217/snpen@s20@a2012@n06061@tS.clean.pdf.

226 CP argentino, art. 303, inc. 1: "Será reprimido con prisión de 3 a 10 años y multa de 2 a 10 veces del monto de la operación, el que convirtiere, transfiriere, administrare, vendiere, gravare, disimulare o de cualquier otro modo pusiere en circulación en el mercado, bienes provenientes de un ilícito penal, con la consecuencia posible que el origen de los bienes originarios o los subrogantes adquieran la apariencia de un origen lícito, y siempre que su valor supere la suma de pesos trescientos mil (\$300.000), sea en un solo acto o por la reiteración de hechos diversos vinculados entre sí".

227 Ley 9.612, art. 1 (Dos Crimes de "Lavagem" ou Ocultação de Bens, Direitos e 
ficada por la Ley $\mathrm{N}^{\circ}$ 12.683). De ambos sistemas legales se aprecia la falta de una expresa declaración acerca de que los delitos tributarios constituirían predicate offences, lo que ha motivado que la doctrina adopte posición frente al asunto. En el caso argentino, autores como Durrieu Figueroa ${ }^{228}$ y Borinsky ${ }^{229}$ sostienen que la reforma de 2011 del delito de lavado de dinero (dispuesta mediante la Ley 26.683, del 21/ Jun/2011), no varió la fórmula contenida en la norma derogada, señalando que el delito previo al del lavado de dinero puede incluir a cualquier delito, incluso los delitos fiscales. Este planteamiento es, sin embargo, contradicho por autores como Díaz ${ }^{230}$, quien considera inviable que la defraudación tributaria pueda ser calificada como delito fuente, por una supuesta carencia de objeto material. Además, con respecto al sistema brasileño, Bitencourt y De Oliveira ${ }^{231}$ sostienen que con su actual reforma (establecida mediante Ley $\mathrm{N}^{\mathrm{o}}$ 12.683), al reemplazarse el sistema del catálogo por uno abierto, los delitos fiscales pueden constituirse en delito precedente.

En España la problemática es similar a la de estos últimos ordenamientos. El art. 301 del CP establece que los bienes objeto del blanqueo han de tener origen en una "actividad delictiva", lo cual ha motivado opiniones contrapuestas en la doctrina. En primer lugar, un sector ${ }^{232}$

Valores): "Ocultar o disimular la naturaleza, origen, localización, disposición, movimiento o propiedad de los bienes, derechos o valores procedentes, directa o indirectamente, de una infracción penal" (Traducción libre).

228 Durrieu Figueroa, R. (2013), El delito tributario y el lavado.... 1 (nota 16).

229 Borinsky, M. (2014), Fraude fiscal. Un estudio histórico, comparado, de derecho penal, tributario, económico y sociológico, Buenos Aires, Ediciones Didot. 425.

230 Díaz, V. (2012), La exégesis del delito de lavado de dinero y la desvinculación con el delito fiscal, en Bertazza, H. / D’Álbora, F. (dirs.), Tratado de lavado de activos y financiación del terrorismo. Prevención, investigación y represión, Tomo I, Buenos Aires, La Ley. 290. Expresando que el debate sobre considerar a los delitos de fraude fiscal como previos al lavado sigue aún abierto, Cfr. Córdoba, F. (2015), Delito de lavado de dinero, Buenos Aires, Hammurabi. 187.

231 Bitencourt, C. R. / De Oliveira Monteiro, L. (2013). Lavagem de dinheiro segundo a legislação, en RBCCrim, Año 21, Vol. 102, maio-junho, São Paulo, Dos Tribunais Ltda. 185-186.

232 Aránguez Sánchez, C. (2000), El delito de blanqueo de capitales, Madrid, Marcial Pons. 187; Palma Herrera, J. M. (2000), Los delitos de blanqueo de capitales, Madrid, Edersa. 274; Abel Souto, M. (2005), El delito de blanqueo de capitales, Barcelona, Bosch. 224; Campos Navas, D. (2005), Lavado de dinero y delito fiscal. Posibilidad de que delito fiscal sea el delito precedente al de blanqueo, en La Ley: Revista jurídica 
considera que la defraudación tributaria (delito de fraude fiscal) es idónea para constituirse en actividad delictiva previa del blanqueo, considerando a la cuota tributaria defraudada como el objeto material de este último. Esta postura ha sido asumida y desarrollada por el Tribunal Supremo español, particularmente, en la STS $\mathbf{N}^{\circ}$ 974/2012 (del 05/Dic/2012; caso "Ballena Blanca") y la STS No 182/2014 (del 11/ Mar/2014). En contradicción con este planteamiento, la línea opuesta de la doctrina ${ }^{233}$ considera, con diferentes matices argumentativos $-\mathrm{a}$

española de doctrina, jurisprudencia y bibliografía, No 5, Madrid, La Ley. 1405. Es conveniente precisar que ambos autores formularon el planteamiento reseñado, con antelación a la reforma de 2010 del CP español (LO 5/2010, de 22 de junio), así como de la emisión de la vigente Ley de prevención del blanqueo de capitales (Ley 10/2010, de 28 de abril). Particularmente, en el caso de Daniel Campos, consideró que ya desde la reforma de 2003 (por la que se reformó el art. 301 del CP español, aludiéndose al "delito" en general como actividad previa idónea para producir bienes objeto del blanqueo), se podía admitir a todos los delitos fiscales como delitos fuente. Además de estos autores, han desarrollado con amplitud el planteamiento que reconoce el carácter de delito previo de la defraudación fiscal, Domínguez Puntas, A. (2011), Delito fiscal y blanqueo.... 291; Blanco Cordero, I. (2011), El delito fiscal como actividad delictiva previa del blanqueo de capitales, en Revista Electrónica de Ciencia Penal y Criminología (RECPC), No 13-1, Universidad de Granada. 2024; Mallada Fernández, C. (2012), Blanqueo de capitales y evasión fiscal, Valladolid, Lex Nova. 174-176; Serrano González De Murillo, J. L. (2013), Delito fiscal y bienes con origen en actividad delictiva como objeto de blanqueo, en Cuadernos de Política Criminal, No 111, Año III, Madrid, Dykinson. 83-84; García Bañuelos, J. A. (2015), El delito fiscal como actividad delictiva previa del delito de blanqueo de capitales, en QF, No 1-2, Navarra, Aranzadi. 107-109.

233 Quintero Olivares, G. (2006), El delito fiscal y el ámbito material del delito de blanqueo, en AJA, No 698, del 17 de abril, Navarra, Aranzadi. 1; Córdoba Roda, J. (2006), Abogacía, secreto profesional y blanqueo de capitales, Madrid, Marcial Pons. 63; Reque Mata, Susana (2009), ¿Puede considerarse el delito fiscal delito previo al delito de blanqueo de capitales?, en I Congreso de prevención y represión del blanqueo de dinero, Valencia, Tirant lo Blanch. 287; Fernández Teruelo, J. (2010), Capítulo 14: Blanqueo de capitales, en Ortiz De Urbina Gimeno, Íñigo (coord.), Memento Experto. Reforma penal 2010. Ley orgánica 5/2010, Madrid, Francis Lefebvre. 325; Choclán Montalvo, J. A. (2011), La aplicación práctica del delito fiscal: Cuestiones y soluciones. Adaptado a la Reforma penal de la L.O. 5/2010, Barcelona, Bosch. 338339; Manjón-Cabeza Olmeda, A. (2012), Un matrimonio de conveniencia: blanqueo de capitales y delito fiscal, en RDP, Año XII, Nº 37, Valladolid, Lex Nova. 37; Fernández Junquera, M. (2012), Defraudación fiscal, blanqueo de capitales y regularización tributaria, en REDF, No 155, julio-setiembre, Navarra, Aranzadi. 33; Luzón Campos, E. 
nuestro juicio, no definitivos, según argumentaremos-, que la cuota tributaria sería inidónea para ser objeto de lavado, con ello, desde dicha posición, sería dogmáticamente inviable concebir a la defraudación fiscal como delito fuente del blanqueo. Este último sector reconoce, conviene precisarlo, como indubitable que determinados delitos tributarios -de estructura distinta a la defraudación fiscal-sí son idóneos para ser considerados como delitos previos: es el caso de aquellos delitos que presentan una tipología similar a la estafa, tales como la obtención indebida de devoluciones o de beneficios fiscales o el fraude de subvenciones.

En relación con el caso español, desde la puesta en vigor de la Ley 10/2010, del 28 de abril (Ley de prevención del blanqueo de capitales y de la financiación del terrorismo), con mayor claridad se ha reconocido que "para efectos de dicha Ley" se entenderá por bienes procedentes de la actividad delictiva a "todo tipo de activos... con inclusión de la «cuota defraudada» en el caso de los delitos contra la Hacienda Pública" (art. 1, inc. 2, penúltimo párrafo). No deja de llamar la atención que, durante la discusión del Anteproyecto de dicha norma administrativa, algunos operadores jurídicos pretendieron encontrar en dicha normativa sectorial un criterio "vinculante" para el delito de blanqueo. En efecto, en sendos informes al Anteproyecto de dicha Ley, tanto el Consejo Fiscal de España ${ }^{234}$ como el Consejo General del Poder Judicial2 ${ }^{235}$, calificaron

(2012), Blanqueo de cuotas defraudadas y la paradoja McFly, en diario La Ley, Sección Tribuna, No 7818, Año XXXIII, del 14 de marzo, Ref. D-120, Madrid, Editorial La Ley. 2; Chico De La Cámara. (2012), El delito de defraudación tributaria tras la reforma del Código penal por la LO 5/2010, Navarra, Aranzadi. 172-173; Del Rosal Blasco, B. (2013), Delito fiscal y blanqueo de capitales: perspectivas ante la nueva reforma del tipo básico del delito fiscal, en diario La Ley. Sección Doctrina, Año XXXIV, No 8017, de 6 de febrero, Ref. D-45, Madrid, Editorial La Ley. 5; Martín Queralt, J. B. (2014), "Delito fiscal y blanqueo de capitales", en García Prats, A. (dir.), Intercambio de información, blanqueo de capitales y lucha contra el fraude fiscal, Madrid, IEF. 33; Sánchez Stewart, N. (2014), La declaración tributaria especial y el blanqueo de capitales, en REDS, No 4, enero-junio, 2014, Madrid, Dykinson. 6; Díaz y García Conlledo, M. (2014), ¿Puede el delito de defraudación tributaria...?. 611; Carrión Morillo, D. (2015), Una aproximación a los problemas actuales del blanqueo de capitales y el delito

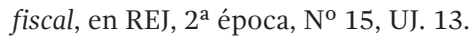

234 Fiscal General del Estado (2009), Informe del Consejo Fiscal sobre el Anteproyecto de Ley de Prevención del Blanqueo de capitales y de la Financiación del terrorismo, del 28 de setiembre, Madrid. 4.

235 Consejo General del Poder Judicial (2009), Informe al Anteproyecto de Ley de Preven- 
tal propuesta normativa como positiva para la persecución del blanqueo de los bienes derivados del delito fiscal, como también para la exclusión de interpretaciones doctrinales contradictorias a dicha consideración.

En adición a lo expresado por tales instituciones, un sector doctrinal consideró que dicha normativa administrativa tiene fundamento "aclarativo". Así, Mallada Fernández sostiene que mediante la Ley 10/2010 (art. 1, inc. 2, penúltimo párrafo), "el legislador simplemente quería aclarar las posibles dudas que podrían surgir en la doctrina y en la jurisprudencia a la hora de interpretar y aplicar estos preceptos" (Mallada Fernández, 2012,172). Sin embargo, según nuestro parecer, tales argumentos, así como los expresados por las referidas instituciones públicas, hacen concluir precisamente en todo lo contrario. Es la propia norma la que califica a la cuota tributaria como susceptible de blanqueo, pero "para efectos de dicha Ley". Es decir, que es idónea para dar base al ilícito administrativo del blanqueo regulada y sancionada en dicha norma. Conviene, por ello, analizar si dicha precisión de contenido administrativo puede ir más allá de la norma preventiva, anulando que la cuota tributaria defraudada pueda tener también relevancia penal (como objeto material del lavado procedente de delitos fiscales). La norma administrativa no puede ni incluir ni excluir al delito de blanqueo, sin que antes se infrinja el principio de reserva de ley. El que cuota tributaria sea un bien susceptible de ser administrativamente blanqueado, y que los actos que se efectúen sobre sí puedan configurar una ilicitud administrativa, no excluye como tampoco incluye al blanqueo delictivo de la cuota tributaria. En suma, la afirmación o negación de los delitos fiscales - con particular incidencia, en la defraudación tributaria- como delitos previos no depende de norma administrativa alguna $^{236}$. Sino, antes bien, de la estructura delictiva prevista en el art. 301 del CP español. En este tipo penal se hace referencia a que los bienes han de proceder de una "actividad delictiva" (Blanco Cordero, 2015, 491) como sin duda lo es la defraudación fiscal. Sin embargo, este último argumento, que puede ser considerado como de carácter formal, no se erige como el fundamento esencial que justifica la calificación del delito de fraude tributario como delito fuente.

ción del Blanqueo de capitales y de la Financiación del terrorismo, del 29 de setiembre, Madrid. 63.

236 A. Martínez-Arrieta Márquez de Prado, I. (2014), El autoblanqueo. El delito fiscal como delito antecedente del blanqueo de capitales, Valencia, Tirant lo Blanch. 22. 
Finalmente, concluyendo este apartado, existen Estados donde es impune el lavado de activos procedentes de delitos tributarios, como es el caso de Uruguay ${ }^{237}$ y Panamá. Debemos no obstante precisar que en estos países se reprime el blanqueo de bienes derivados de delitos de contrabando -en ambos Estados- y aduaneros -solo en el segundo-. Por tanto, en estos ordenamientos jurídicos, caracterizados por el empleo del sistema del catálogo o de numerus clausus en la determinación del delito fuente, se constata la ausencia de los delitos tributarios como hechos precedentes susceptibles de dar lugar al lavado de activos.

\section{REGULACIÓN EN EL PERÚ}

Desde la puesta en vigor de la Ley No 27765 (del 27/Jun/2002) el sistema penal peruano incorporó a la "defraudación tributaria" conducta delictiva prevista, junto a sus modalidades, en los arts. 1 al 4 de la Ley Penal Tributaria (DLeg No 813, del 19/Abr/1996)- como delito precedente, sin hacer expresa distinción de entre sus varias modalidades de realización típica. Si bien las propuestas legislativas que motivaron el debate y posterior aprobación de dicha Ley (Proyectos de Ley No 01084-2001/CR, del 22/Oct/2001, y No 01931-2001/CR, del 30/Ene/2002) no contemplaron expresamente a la "defraudación tributaria" como delito fuente. Sin embargo, sí fue incluida como tal en el Texto Sustitutorio de los aludidos Proyectos de Ley, conforme al correspondiente Dictamen de la Comisión de Justicia del Congreso de la República del Perú (del 08/May/2002).

Los contornos ya amplios de dicho delito fuente -la defraudación tributaria-, inalterados durante 10 años, fueron expandidos aún más por el Poder Ejecutivo al emitir, vía delegación congresal, el DLeg $\mathrm{N}^{\circ}$ 1106 (del 19/Abr/2012). Esta norma, al derogar la Ley No 27765, reemplazó -en su art. 10, segundo párrafo- la referencia al delito de "defraudación tributaria” por la más genérica expresión "delitos tributarios", sin que puedan identificarse las razones de dicha modificatoria ni en el texto de la norma referida, ni en la Ley autoritativa $\mathrm{N}^{\circ} 29815$ (del 22/Dic/2011) ${ }^{238}$. Es probable que, durante la actividad legislativa

237 En un tratamiento más amplio, Galain Palermo, P. (2015). Lavado de activos en Uruguay: Una visión criminológica, en Ambos, K., Caro Coria, C. y Malarino, E. (coords.), Lavado de activos y compliance, Lima, Jurista Editores. 334.

238 Ley No 29815 (del 22/Dic/2011), Ley autoritativa con la cual se delegó la facultad legislativa al Poder Ejecutivo y fundamentó la emisión del DLeg No 1106 -Decreto 
delagada en favor del Poder Ejecutivo, se haya empleado la versión actualizada en febrero de 2012 de las Recomendaciones del GAFI (emitida apenas dos meses después de la autorización de la facultad de legislar, y dos meses antes de la promulgación del DLeg No 1106). Como se ha tenido ocasión de explicar, en la versión de 2012, a diferencia de su inmediata anterior -la de 2003-, el GAFI incorporó explícitamente en su glosario de definiciones, y por vez primera, a los "delitos tributarios" como hecho base del lavado de activos. De ser el caso que este aspecto de la reforma del delito de lavado tuvo por base las novedades procedentes del soft law, hubiere merecido una justificación razonable y, sobre todo, transparente en el texto del DLeg No 1106.

En tal sentido, ya decidida la incorporación de los "delitos tributarios" como actividad criminal fuente del lavado, todavía existen escasos pronunciamientos de la doctrina peruana en el sentido de negar o admitir que la "defraudación tributaria" pueda constituirse en delito precedente. En términos generales, entre quienes rechazan que la defraudación tributaria por elusión del pago de tributos pueda configurarse en delito fuente, se encuentran Gálvez Villegas ${ }^{239}$ y García Cavero $^{240}$. Debemos precisar, sin embargo, que ambos autores admiten - de forma similar al modo como se presenta la discusión en Españaque determinados delitos tributarios son idóneos para constituirse en delito precedente. Es el caso de los delitos de no entrega indebida de retenciones o percepciones tributarias (art. 2, lit. ${ }^{241}$, de la Ley Penal Tributaria), y del delito de obtención fraudulenta de devoluciones o beneficios fiscales (art. 4, lit. $\mathrm{a}^{242}$, de dicha norma). Finalmente, desde

Legislativo de Lucha eficaz contra el lavado de activos y otros delitos relacionados con la minería ilegal y el crimen organizado-.

239 Gálvez Villegas, T. (2014), El delito de lavado de activos, Lima, Instituto Pacífic 104 y ss; Él mismo (2009), El delito de lavado de activos. Criterios sustantivos y procesales. Análisis de la Ley $\mathrm{N}^{\circ}$ 27765, Lima, Jurista Editores. 86.

240 García Cavero, P. (2015), El delito de lavado de activos, Lima, Jurista Editores.

241 Conforme al art. 2, lit. b, de la Ley Penal Tributaria (DLeg No 813, del 19/Abr/1996): "Son modalidades de defraudación tributaria reprimidas con la pena del artículo anterior: (...)

b) No entregar al acreedor tributario el monto de las retenciones o percepciones de tributos que se hubieren efectuado, dentro del plazo que para hacerlo fijen las leyes y reglamentos pertinentes".

242 De acuerdo con el art. 4, lit. a, de la Ley Penal Tributaria (DLeg No 813, del 19/ Abr/1996): La defraudación tributaria será reprimida con pena privativa de libertad no menor de 8 ni mayor de 12 años... cuando: 
la perspectiva opuesta, otro sector considera que no existe inviabilidad dogmática para concebir a la defraudación tributaria como delito fuente. En esta posición se sitúan Caro Coria ${ }^{243}$ y, sobre la base de la previsión legal, Hinostroza Pariachi ${ }^{244}$.

\section{POSTURAS SOBRE LA PRESUNTA INADMISIBILIDAD DE LA DEFRAUDACIÓN TRIBUTARIA COMO DELITO FUENTE}

\subsection{Ausencia de objeto material por licitud de los activos}

Uno de los principales argumentos sostenidos por quienes consideran como inadmisible que la defraudación tributaria constituya delito fuente radica en la presunta ausencia del objeto material (esto es, que los bienes han de tener origen delictuoso). Dado que en los arts. 1, 2 y 3 del DLeg $\mathrm{N}^{\circ} 1106$ el legislador peruano exige que los actos de lavado se ejerzan sobre bienes de "origen" delictivo (activos "producidos" o "generados" por una actividad criminal previa), a criterio de esta argumentación, el defraudador tributario no origina -no produce o genera- ni obtiene causalmente algo que antes -de dicho delito- no hubiere tenido ya. Antes bien, aquel tendría en su esfera de dominio bienes originados en actividades económicas lícitas (aunque no tributadas). De modo que la cuota tributaria impaga no estaría originada en el delito de defraudación tributaria, sino situada lícitamente en el patrimonio del sujeto, al haber sido obtenida mediante actividades mercantiles u otras de carácter legal. Por lo que los activos -según considera este sector doctrinal-al carecer de "ilicitud", devienen en inidóneos como objeto material del lavado. En suma, la falta del objeto típico demostraría la inviabilidad de un pretendido delito de lavado.

En el Perú -adoptando la postura de un sector de la doctrina española-, Gálvez Villegas señala que "asumiendo los criterios de Choclán Montalvo y Quintero Olivares, hemos sostenido que en los delitos de

a) Se obtengan exoneraciones o inafectaciones, reintegros, saldos a favor, crédito fiscal, compensaciones, devoluciones, beneficios o incentivos tributarios, simulando la existencia de hechos que permitan gozar de los mismos.

243 Caro Coria, C. (2015), "Lavado de activos provenientes del delito tributario", en Ambos, Kai / Caro Coria, Carlos / Malarino, Ezequiel (coords.), Lavado de activos y compliance. Perspectiva internacional y derecho comparado, Lima, Jurista Editores. 155-156.

244 Hinostroza Pariachi, C. (2009), El delito de lavado de activos, Lima, Grijley. 179-180. 
omisión, como en los casos de delitos tributarios cometidos al dejar de pagar determinada obligación tributaria, resulta discutible si la cantidad dejada de pagar, y que permanece en el patrimonio del agente, constituye objeto, efectos o ganancias del delito... en este caso el dinero no ha sido producido o ganado con la omisión del pago (comisión del delito tributario); pues este dinero se ha obtenido por otros medios lícitos, y, por lo tanto, sobre ellos el agente tiene titularidad" Gálvez Villegas $(2014,104)$. En similar sentido, Alpaca Pérez sostiene que la defraudación tributaria "no puede constituirse como un delito previo del delito de lavado de activos. La cantidad dineraria que ha sido dejada de pagar de manera fraudulenta (la cuota defraudada) no tiene un origen en el delito de defraudación tributaria: su origen puede ser uno absolutamente lícito (producto de su actividad laboral regular, por ejemplo)" ${ }^{245}$.

En España, una línea de opinión -representada por Córdoba Roda ${ }^{246}$, Fernández Teruelo ${ }^{247}$, Luzón Campos ${ }^{248}$, Fernández Junquera ${ }^{249}$, del Rosal Blasco ${ }^{250}$, Martín Queralt ${ }^{251}$ y Carrión Morillo ${ }^{252}$ - considera que la defraudación tributaria carecería de idoneidad para configurarse en delito fuente, debido a que los bienes - objeto de las diversas conductas incriminadas como blanqueo- no tendrían un origen delictivo. Antes bien, se trataría de activos de procedencia lícita, explicable en actividades comerciales, mercantiles u otras legales capaces de producir rendimientos económicos ${ }^{253}$. Al respecto, Choclán Montalvo considera que "el hecho del que traen causa los bienes debe ser típico y antijurídico. No lo es, por ejemplo, un negocio jurídico lícito, por mucho que con ocasión de ese negocio se devengue un impuesto, posteriormente

245 Alpaca Pérez, A. (2016), Delincuencia organizada, delitos tributarios y lavado de activos, en Zúñiga Rodríguez, L. (dira) / Mendoza Llamacponcca, F. (coord.), Ley contra el Crimen organizado (Ley $N^{o}$ 30077). Aspectos sustantivos, procesales y de ejecución penal, Lima, Instituto Pacífico. 631.

246 Córdoba Roda, J. (2006), Abogacía, secreto profesional.... 63-64.

247 Fernández Teruelo, J. (2010), Capítulo 14: Blanqueo.... 325.

248 Luzón Campos, E. (2012), Blanqueo de cuotas defraudadas.... 2-4.

249 Fernández Junquera, M. (2012), Defraudación fiscal, blanqueo de capitales.... 24 y 33.

250 Del Rosal Blasco, B. (2013), Delito fiscal y blanqueo.... 5.

251 Martín Queralt, J. B. (2014), Delito fiscal y blanqueo.... 33.

252 Carrión Morillo, D. (2015), Una aproximación a los problemas.... 13.

253 En Argentina, esta argumentación es sostenida, entre otros, por Díaz, V. (2012), La exégesis del delito de lavado.... 290. 
eludido. No puede apreciarse delito de blanqueo de capitales cuando el origen de los fondos es conocidamente lícito" ${ }^{254}$. En el mismo sentido, Quintero Olivares asevera que debe existir una relación de causa-efecto entre el delito fuente y los bienes que este produce, de modo tal que el autor obtenga "algo que no tenía antes del delito y que es valioso en términos de dinero" ${ }^{255}$. Finalmente, Díaz y García Conlledo concluye en lo problemático de aceptar "que lo defraudado en el delito fiscal citado pueda ser considerado «bienes» sobre los que recaigan las conductas típicas" ${ }^{256}$.

\section{2 Atipicidad por imposibilidad de individualización de la cuota tributaria defraudada dentro del patrimonio lícito}

También se ha considerado inviable la tipicidad del lavado procedente de la defraudación tributaria, a partir de las dificultades surgidas en la ineludible labor de individualización de la cuota tributaria defraudada dentro del patrimonio lícito del agente. Al respecto, en el Perú, señala García Cavero que "lo complicado está más bien en los delitos que simplemente ahorran un gasto, como sucede, por ejemplo, con la defraudación tributaria. En este caso no es posible individualizar dentro del patrimonio del autor la parte que corresponde al egreso no realizado como consecuencia del delito... Por lo tanto, no sería posible la comisión de un delito de lavado de activos”257.

En efecto, limita ilegítimamente la libertad de acción, y el derecho a la propiedad, decidirse que el íntegro del patrimonio del autor se ve contaminado por el solo hecho que se ha incorporado a este activos de origen delictivo. Sería, pues, absurdo considerar que los bienes de origen no delictivo fueren -junto a los de fuente delictuosa- objeto del delito de lavado de activos. Sin embargo, la confusión de bienes de origen lícito con los de procedencia criminal, que motiva la discusión acerca de si el íntegro del patrimonio se ve contaminado, no es un problema privativo al delito de defraudación tributaria ${ }^{258}$. Esta cuestión no es intrínseca y excluyente de la defraudación, sino que se presenta

254 Choclán Montalvo, J. A. (2011), La aplicación práctica.... 337.

255 Quintero Olivares, G. (2006), El delito fiscal y el ámbito material.... 6.

256 Díaz y García Conlledo, M. (2014), ¿Puede el delito de defraudación tributaria...?. 624-625.

257 García Cavero, P. (2015), El delito de lavado.... 121.

258 Serrano González de Murillo, J. L. (2013), Delito fiscal y bienes.... 86-87. 
en cualquier delito fuente cuyos rendimientos económicos (principalmente, dinero) hayan sido mezclados con patrimonios lícitos. En consecuencia, considerar que la supuesta imposibilidad para individualizar la parte correspondiente al egreso que no se efectuó a favor del Estado, como sustento para descalificar a la defraudación tributaria como delito previo, constituye a nuestro juicio un argumento que soslaya o elude que esta misma problemática se presenta en todo delito fuente. Por tanto, no añade nada que justifique tal rechazo.

En suma, las dificultades para individualizar e identificar razonablemente los activos de procedencia delictiva y su diferenciación del resto del patrimonio lícito, se presentan en todos los delitos precedentes -por ejemplo, se tiene el mismo problema en el caso de activos procedentes del narcotráfico que se encontraban ingresados en una cuenta bancaria en la que existían adicionalmente fondos de origen legal-, aun cuando en el caso de la defraudación tributaria existan determinadas particularidades. Se trata pues de un problema transversal que afecta a cualquier actividad delictiva previa, con especial incidencia en aquella que produce dinero, objeto material caracterizado por su alta fungibilidad ${ }^{259}$. Considerar que las dificultades de tal individualización justificarían la presunta inadmisibilidad de la defraudación fiscal como delito fuente, entraña la consecuencia ilegítima que en todos los casos de mezcla (o confusión del patrimonio lícito -con el de origen delictuoso-), no se podría configurar el delito de lavado de activos.

\section{3 Inidoneidad del objeto por ausencia de relación de causalidad (inexistencia de desplazamiento patrimonial)}

Un sector doctrinal argumenta que sería indispensable identificar una relación de causalidad entre el delito previo y los rendimientos económicos que este ha de producir. La idoneidad de un delito fuente -según este criterio- dependerá de confirmar la existencia de un nexo causal de desplazamiento patrimonial de los bienes delictivos, hacia la esfera de dominio de quien -con posterioridad- realice los actos de lavado. Esta secuencia, conforme sostiene dicho sector, sería imposible en el caso de los delitos omisivos. En el Perú, por ejemplo, Gálvez Villegas sostiene que "con la omisión del pago no se ha de-

259 García Bañuelos, J. A. (2015), El delito fiscal como actividad delictiva previa.... 102103. 
terminado la relación causal que permita sostener que dicha omisión generó un activo patrimonial para el sujeto y que sobre este activo pueden concretarse las acciones propias del delito de lavado" ${ }^{260}$.

En España, Fernández Teruelo sostiene que en el delito de defraudación fiscal el producto (dinero o bienes) "ya está en el patrimonio del sujeto, por lo que no son bienes «provenientes de» ninguna actividad delictiva” ${ }^{261}$. Según su parecer, solo cuando pueda establecerse un desplazamiento patrimonial sería posible configurarse un delito fuente. En el ámbito de los delitos tributarios, sostiene dicho autor, esto solo sería predicable "del fraude de subvenciones, donde sí se produce traslación del dinero" ${ }^{62}$. Con similar discernimiento, Chico de la Cámara refiere que únicamente son delitos previos tributarios la obtención indebida de devoluciones o el fraude en las subvenciones "donde sí se produce técnicamente la traslación del dinero" ${ }^{263}$. Así también, Del Rosal Blasco señala que en la defraudación tributaria "no se puede establecer relación causal entre la acción omitida y los bienes ya incorporados al patrimonio del sujeto por virtud de un hecho positivo anterior no constitutivo de delito" ${ }^{264}$.

Finalmente, Choclán Montalvo sostiene que la defraudación fiscal, por tratarse -según su postura- de un delito omisivo, carecería de idoneidad para dar base al lavado de activos. Este autor considera que "la omisión en sentido científico-natural no causa nada. Un delito que responda en su configuración típica al patrón de los delitos de omisión... no puede servir de delito previo de un delito de blanqueo de capitales, pues no puede establecerse relación causal entre la acción omitida (el pago de los tributos) y los bienes ya incorporados al patrimonio del sujeto por virtud de un hecho positivo anterior no constitutivo de delito (verdadera causa de la incorporación del bien)" ${ }^{265}$. Debe reconocerse que el planteamiento de este autor es empleado unifor-

260 Gálvez Villegas, T. (2014), El delito de lavado.... 104

261 Fernández Teruelo, J. (2010), Capítulo 14: Blanqueo de capitales, en Ortiz de Urbina Gimeno, Íñigo (coord.), Memento Experto. Reforma penal 2010. Ley orgánica 5/2010, Madrid, Ediciones Francis Lefebvre. 325.

262 Ibidem. 325-326.

263 Chico de la Cámara, P. (2012), El delito de defraudación tributaria.... 173.

264 Del Rosal Blasco, B. (2013), Delito fiscal y blanqueo.... 5.

265 Choclán Montalvo, J. A. (2011), La aplicación práctica.... 339. 
memente por la doctrina de España ${ }^{266}$ y del Perú ${ }^{267}$, para justificar la presunta inidoneidad de la defraudación tributaria como delito fuente.

\section{4 Presunta infracción de las garantías del non bis in idem y a la no autoincriminación}

El delito de defraudación fiscal reprime a quien, mediante actos fraudulentos, no paga (total o parcialmente) los tributos fijados en las leyes. El autor de este delito es quien conserva la cuota tributaria defrauda dentro de su esfera de dominio, infringiendo su deber de desprenderse de dicho patrimonio afecto y trasladarlo al órgano de recaudación fiscal -vencido el plazo legal-. En estos casos es el propio autor de la defraudación fiscal quien, conociendo que parte de sus rendimientos está sometido al pago de tributos, se vale de maniobras fraudulentas para no efectuar dicho desembolso a favor de su legítimo propietario.

Al constatarse que el defraudador se encuentra, seguidamente, en posesión de activos que no le pertenecen (sino al fisco), es razonable apreciar que él mismo efectúe actos de disposición sobre dicho monto no ingresado. Aquí surge la cuestión de si es compatible con las garantías del non bis in idem y a la no autoincriminación, sancionar penalmente como lavado dichos actos de disponibilidad (conversión o transferencia) o de mera posesión, ejecutados sobre los activos mantenidos fraudulentamente en la propia esfera de dominio -y no desembolsados al fisco-. Así, en el debate acerca de la viabilidad típica del lavado de activos procedente del delito de defraudación fiscal, un sector de la doctrina ha buscado incorporar los presupuestos y consecuencias de la discusión dogmática sobre la tipicidad del autolavado.

Con relación a la primera de las garantías, señala Dópico Gómez-Aller, si la conversión o transmisión de dinero "con origen en un delito fiscal

266 Gómez Benítez, J. M. (2006), Reflexiones técnicas y de política criminal.... 74 y 81; Bacigalupo Zapater, E. (2012), Sobre el concurso de delito fiscal.... 35-36; Manjón-Cabeza Olmeda, A. (2012), Un matrimonio de conveniencia: blanqueo de capitales.... 38; Del Rosal Blasco, B. (2013), Delito fiscal y blanqueo.... 5; Martín Queralt, J. B. (2014), Delito fiscal y blanqueo.... 33; Sánchez Huete, M. A. (2016), La Administración Tributaria ante el delito. La nueva regularización voluntaria, en QF, No 7, abril, Navarra, Aranzadi. 39.

267 Gálvez Villegas, T. (2014), El delito de lavado.... 104-105. 
fuese delito de blanqueo, todo delito de elusión tributaria traería consigo necesariamente un adicional delito de blanqueo"268. Según este razonamiento, en los supuestos de defraudación tributaria, supuestamente, quien defrauda mantiene en su poder (posee o inmediatamente utiliza) los activos no ingresados al fisco. Con lo que, seguidamente $-\mathrm{y}$ es lo que tal sector objeta- se estaría calificando tal proceder como un delito de lavado (principalmente, en la modalidad de "mantención en el poder", "posesión" o "utilización"), lo cual sería irreconciliable con la garantía del non bis in idem. Sin embargo, contra dicha argumentación -que se suma al rechazo de considerar como delito fuente al delito de defraudación fiscal-, cabe dirigir algunas observaciones.

En primer lugar, la garantía del non bis in idem se estructura a través de la exigencia de triple identidad (de sujeto, hecho y fundamento), de modo que la infracción de dicha garantía dependerá que dos investigaciones se sustancien concurriendo dicha tiple exigencia. En lo que constituye objeto de debate, si bien quien defrauda (no trasladando la cuota tributaria a su legítimo propietario, mediante actos fraudulentos) es la misma persona que, al mismo tiempo, mantiene en su dominio dicho bien, en apariencia se cumpliría la identidad de sujeto. Sin embargo, dada la sustantivad del delito de lavado de activos es, indubitablemente, su desvalor va más allá del simple y solo hecho de poseer (incluso convertir o transferir) rendimientos económicos delictuosos. Por lo que es indispensable, para afirmar la concurrencia de su injusto penal, que las operaciones económicas realizadas, o la posesión de los activos criminales, se efectúen con la finalidad de evitar la identificación del origen de los activos, su incautación o decomiso.

Por tanto, no se configura el lavado por la simple posesión o mantención en el poder de bienes de origen ilícito. Establecer lo contrario es banalizar, sino eludir, el componente material del injusto típico del blanqueo. Este delito es más que la simple posesión de, en este caso, la cuota tributaria. Por ello, en el análisis de las relaciones entre el delito de lavado de activos y la defraudación tributaria, desde nuestra perspectiva, no se cumple la identidad de hecho.

En segundo lugar, con la prohibición penal de blanquear bienes se pretende proteger, a través de una estructura típica de peligro abstracto, a la libre y leal competencia -según hemos defendido supra-.

268 Dópico Gómez-Aller, J. (2010), Si todo es blanqueo, nada es blanqueo”, en LegalToday.com, del 15 de enero, Madrid. 1. 
Mientras que, por su parte, la represión del delito de defraudación fiscal pretende poner en resguardo a la función recaudatoria y de administración de los tributos. De modo que el desvalor del citado delito tributario, no abarca el desvalor del delito de lavado de activos, con ello, la defraudación fiscal en su relación con el blanqueo no se cumple la identidad de fundamento.

Por ello, cuando se argumenta que toda elusión fiscal traería consigo necesariamente un delito de lavado ${ }^{269}$, se parte -desde nuestra perspectiva- de forma prejuzgada en calificar como blanqueo lo que no es. Este delito, conforme se ha puesto de relieve, va más allá de la mera posesión, su desvalor no abarca el simple hecho de mantener en el poder determinados bienes (de oriden delictuoso). La posesión de bienes per se no califica como delito de lavado, ni debe ser limitada a caracterizársela como "lavado", si esta no se sitúa en el contexto general del proceso de reciclaje (que va desde el inicio de los actos de colocación hasta el retorno de los bienes al tráfico económico con apariencia de legalidad). De modo que la "posesión" solo es calificable como delito de lavado, si se efectúa con la finalidad de "ocultar o encubrir" el origen criminal de los activos o de "evitar identificar" dicha procedencia. Quien eludió pagar tributos, mediante actos fraudulentos, si bien no deja de poseer ciertos bienes (la cuota tributaria defraudada) dentro de su patrimonio, ese solo hecho no califica como blanqueo. En suma, ni se infringe la prohibición del bin in idem, por carecer de afectación alguna a la identidad de fundamento, ni tampoco constituye un argumento sólido para fundamentar la presunta inidoneidad de la defraudación fiscal como delito fuente.

En suma, el argumento acerca que la admisión de la defraudación tributaria como delito previo infringiría la garantía del non bis in idem no podemos compartirlo como el fundamento por el cual dicho delito carecería de idoneidad para dar base al blanqueo. No solo por no obedecer al contenido material de la garantía que se dice resguardar, sino inclusive por carecer de suficiencia para superar el propio test que le da contenido (la triple identidad de sujeto, hecho y fundamento).

Desde otro enfoque, también se sostiene que constituye un mero acto de agotamiento el hecho de mantener en el poder o utilizar los efectos económicos de un delito provechoso. En este caso, que el au-

269 Como sostiene Dópico Gómez-Aller, J. (2010), Si todo es blanqueo, nada es blanqueo. 1. 
tor de la defraudación fiscal mantenga en su poder o utilice (o realice actos de disposición) la cuota tributaria que no ingresó al fisco, constituiría una consecuencia necesaria e inmediata de dicho delito tributario. Por lo que, a menos que se autodenuncie, se desista o pague inmediatamente al fisco la cuota tributaria, junto al delito fiscal el defraudador cometería ineludiblemente el blanqueo ${ }^{270}$. En suma, concluye la postura examinada, que una exigencia de tal naturaleza infringiría el derecho a la no autoincriminación.

Debemos, sin embargo, reafirmar que el delito de lavado de activos, conforme hemos puesto de relieve, va más allá de sola posesión de bienes (representados, en el caso de la defraudación tributaria, por la cuota tributaria no ingresada al fisco mediante actos fraudulentos) o de su mantención dentro del radio de disposición patrimonial. Antes bien, el delito de blanqueo requiere concretos e identificados actos posteriores, distintos al delito fiscal previo (que se consuma con el impago fraudulento de los tributos), los cuales debe ser efectuados en un contexto de preparación, desarrollo o cierre del circuito de reciclaje. Por consiguiente, coincidiendo con Caro Coria ${ }^{271}$, la norma penal que subyace a la incriminación del blanqueo no establece un deber de autoinculpación, antes bien la obligación que se evite la circulación de bienes con fuente criminal en el tráfico económico legal. No existe un mandato de autodenunciarse sino de no transferir (o de no convertir) activos de procedencia delictuosa.

\subsection{Postura personal: Idoneidad de la defraudación tributaria para constituirse en delito fuente}

\section{i. Voluntad legislativa}

En el Perú, desde que fue puesta en vigor la Ley No 27765 (del 27/ Jun/2002), con la que por vez primera se reprimió el lavado procedente de delitos distintos al narcotráfico o narcoterrorismo, el legislador había contemplado (en su art. $6^{272}$, párrafo segundo) como hecho cri-

270 Dópico Gómez-Aller, J. (2010), Si todo es blanqueo, nada es blanqueo. 1.

271 Caro Coria, C. (2015), Lavado de activos provenientes.... 179-180.

272 El art. 6 de la Ley No 27765 (de la derogada Ley penal contra el lavado de activos, vigente para los procesos que se siguen por hechos cometidos durante su vigor), previó que: "El origen ilícito que conoce o puede presumir el agente del delito podrá inferirse de los indicios concurrentes en cada caso. 
minal precedente al delito de "defraudación tributaria", sin hacer distinciones sobre cuál modalidad de este delito era susceptible de dar base al lavado. Reemplazada dicha ley por efectos del DLeg $N^{0} 1106$ (del 19/Abr/2012), la voluntad legislativa se encaminó hacia ampliar dicha consideración por la más genérica expresión "delitos tributarios". De dicha forma, el Estado peruano asimiló las disposiciones del soft law que había establecido, dos meses antes, la incorporación de los delitos fiscales como delitos previos al lavado (revisión de las recomendaciones del GAFI, a febrero de 2012).

Por ello, aunque pueda calificarse como un criterio formal, el delito de defraudación tributaria constituye actividad criminal idónea para dar base al lavado de activos desde junio de 2002. Sin hacerse distinción de si todos o algunos de los delitos de defraudación contra el fisco constituyen delitos fuente. Esta situación confirmada, en abril de 2012, al haber el legislador decido ampliar "expresamente" esta tipología de delitos fuente hacia todos los otros delitos fiscales. Esto no quiere decir que recién, a partir de 2012, los delitos tributarios puedan ser idóneos para dar base al lavado de activos en el Perú, ya que tal condición podía ser desprendida -desde 2002- de la propia cláusula general establecida en el art. 6, párrafo segundo, de la Ley No 27765. La cual establecía que el origen ilícito de los activos corresponde a los delitos definidos en dicha ley, inclusivo aquellos "otros similares que generen ganancias ilegales". En tal sentido, siempre que se trate de los delitos tributarios graves y vinculados con el crimen organizado -por tanto "similares" a la lista ejemplificativa dispuesta en dicho precepto-, y sean susceptibles de producir ganancias ilícitas, podían configurase en delitos previos desde abril de 2002.

La problemática acerca de la idoneidad o no de la defraudación tributaria como delito fuente se sitúa en la modalidad de eludir o dejar de pagar (total o parcialmente) mediante actos defraudatorios los tri-

El conocimiento del origen ilícito que debe conocer o presumir el agente de los delitos que contempla la presente ley, corresponde a conductas punibles en la legislación penal como el tráfico ilícito de drogas; delitos contra la administración pública; secuestro; proxenetismo; tráfico de menores; defraudación tributaria; delitos aduaneros $\mathrm{u}$ otros similares que generen ganancias ilegales, con excepción de los actos contemplados en el art. 194 CP (receptación).

En los delitos materia de la presente ley, no es necesario que las actividades ilícitas que produjeron el dinero, los bienes, efectos o ganancias, se encuentren sometidas a investigación, proceso judicial o hayan sido objeto de sentencia condenatoria”. 
butos fijados en las leyes. Es el caso del art. 1 de la Ley Penal Tributaria (DLeg No 813, del 19/Abr/1996), el cual establece que: "El que, en provecho propio o de un tercero, valiéndose de cualquier artificio, engaño, astucia, ardid u otra forma fraudulenta, deja de pagar en todo o en parte los tributos que establecen las leyes, será reprimido con pena privativa de libertad no menor de 5 ni mayor de 8 años...". Conforme se aprecia de la estructura de este tipo penal, nos encontramos ante uno de los denominados delitos provechosos o de aprovechamiento.

\section{ii. Diferenciación entre delitos que producen enriquecimiento con la entrada de bienes al patrimonio y delitos de incumplimiento del de- ber de disposición patrimonial}

Los actos reprimidos como delito de blanqueo deben ser efectuados sobre bienes, dinero, efectos o ganancias que procedan (directa o indirectamente) de actividades criminales caracterizadas por su aptitud para producir rendimientos económicos. El producto del delito, de acuerdo con lo dispuesto por el art. 2, lit. e, de la Convención de Palermo de 2000 y, también, de la Convención de Mérida de 2003, está conformado por bienes derivados u obtenidos directa o indirectamente de la comisión de un delito ${ }^{273}$.

Por tanto, la determinación del origen delictivo - denominado también como contaminación del objeto material ${ }^{274}$ - se establece, por una parte, mediante la comprobación de un vínculo o nexo directo entre el delito fuente y los activos producidos. Por ello, tiene origen "directo" en un delito tanto las ganancias, el precio, la recompensa, la promesa de pago -establecida para la comisión de un delito-, el producto -susceptible de tráfico económico, que resulta luego de cometerse el acto criminal-, como, en ocasiones, también el propio objeto material del delito previo.

Asimismo, la contaminación de los activos producidos por el delito previo puede también establecerse mediante un vínculo o nexo indirecto. Esto es, se admite como objeto material del lavado de activos a los bienes "derivados" de aquellos otros que, previamente, han proce-

273 En términos idénticos se defines al producto del delito en el art. 2, lit. e, de la Convención de Mérida de 2003, así también, de modo similar, en el art. 1, lit. a, de la Convención de Varsovia de 2005. Además, tal terminología fue también incorporada, aunque con restricción al narcotráfico, en el art. 1, lit. p, de la Convención de Viena de 1988.

274 Aránguez Sánchez, C. (2000), El delito de blanqueo.... 203. 
dido del delito previo. En estos supuestos de contaminación indirecta se incluye a los bienes que han sufrido sustituciones anteriores, por ejemplo, producidos por diferentes negocios jurídicos de intercambio -las compraventas, permutas o hipotecas-. En estos casos es el propio delito de blanqueo el que se constituye en delito fuente.

Debe ponerse atención que, según sostenemos, el nexo de procedencia delictiva de los activos -o vínculo de contaminación (directa o indirecta) - no puede establecerse mediante superados criterios naturalísticos o de mera causalidad. En tal sentido, disentimos de la postura de Blanco Cordero, quien sostiene que "la conexión entre el bien y la actividad delictiva previa ha de ser de tipo causal" 275 . A nuestro juicio, el vínculo de contaminación delictiva (en los "delitos que producen enriquecimiento con la entrada de los bienes al patrimonio", no así en los "delitos efectuados por incumplimiento del deber jurídico penal de disposición patrimonial”, conforme será desarrollado) no se determina en función de la mera relación causal. Basarse en criterios de determinación naturalística impondría aceptar, si se busca ser coherente con la propia teoría, tanto la indebida tesis del contagio total del patrimonio (el cual pudo haber tenido alguna relación con ganancias delictivas) - que rechazamos-, cuanto calificar como delito de blanqueo a cualquier vínculo negocial realizado con este tipo de patrimonio, con base en la ilimitada e infinita cadena causal. Por tanto, es indispensable establecer la reducción teleológica o normativa del nexo meramente causal que exista entre el delito previo y los bienes que este produce.

Es, en consecuencia, la identificación del fin de protección de la norma del lavado, la herramienta que permite limitar la indefinida contaminación del objeto al que se le situaría, por el empleo de métodos estrictamente causales en la determinación de dicho nexo. El empleo del método causalista entraña la conclusión que toda intervención en algún punto de la cadena de operaciones económicas, como las adquisiciones o transmisiones, efectuadas sobre los bienes maculados (por su origen delictuoso), debería de constituir delito de lavado de activos, lo que, desde luego, constituye un despróposito legal. Antes bien, el análisis teleológico del tipo penal de blanqueo permite advertir que el

275 Blanco Cordero, I. (2011), El delito fiscal como actividad delictiva previa... 21. De acuerdo con el planteamiento de este autor, sostiene Covadonga Mallada, la relación causal exige que el autor obtenga algo que antes no tenía, Cfr. Mallada Fernández, C. (2012), Blanqueo de capitales.... 175. 
puro nexo de causalidad es penalmente irrelevante para la atribución del alcance de la contaminación, o mácula de los bienes producidos (causalmente) por el delito, y su nexo jurídico con aquel ${ }^{276}$.

Debemos, sin embargo, precisar, como ha sido anotado, que para la determinación del nexo jurídico de contaminación (directa o indirecta) de los activos, debe examinarse la estructura morfológica del delito fuente (que constituya objeto de análisis). Por ello es ineludible identificar cuándo nos encontramos, primero, ante aquellos delitos previos caracterizados por producir rendimientos económicos capaces de ingresar en la esfera de dominio patrimonial del propio autor o de terceros $^{277}$. En su contraste con aquellos otros que -por el contrario- no producen activos que ingresan a la esfera de dominio patrimonial del interviniente; sino que, por encontrarse los activos, con antelación al delito, dentro de la propia esfera lícita de disposición del autor, la represión (de estos otros delitos fuente) se fundamenta en el incumplimiento de los deberes jurídico penales de disposición patrimonial ${ }^{278}$.

En primer lugar, por regla general, los delitos idóneos para producir rendimientos económicos presentan una "naturaleza resultativa". De modo tal que, con su realización, puede identificarse que las ganancias o rendimientos ilícitos son causados o producidos como resultado de la comisión delictiva (así, por ejemplo, en los delitos de tráfico ilícito de drogas, corrupción, trata de personas, secuestro, extorsión, minería ilegal u otros similares, en todos estos se aprecia una manifiesta idoneidad para que, con la comisión delictiva, se produzca "como resultado" la obtención de ganancias ilegales).

Estamos pues ante delitos que son idóneos para producir el resultado de generación de bienes o rentas con origen delictuoso, sobre los cuales es, indudablemente viable la comisión del delito de lavado de activos. En suma, la característica principal de estos delitos fuente

276 Esta verificación ha llevado incluso a sostener a un sector de la doctrina que la relación entre la actividad criminal precedente, de donde proviene el objeto material, y el delito de lavado de activos, se configura en un vínculo de imputación objetiva, Cfr. Caro Coria, C., Reyna Alfaro. L. M. y Reátegui Sánchez, J. (2016), Derecho Penal Económico, Tomo II, Lima, Jurista Editores. 663.

277 García Cavero, P. (2015), El delito de lavado.... 120.

278 Blanco Cordero, I. (2011), El delito fiscal como actividad delictiva previa.. 23. 
radica en la producción de ganancias capaces de ingresar a la esfera de dominio patrimonial de sus autores o de terceros. Es decir, estos delitos son fuente, causa u origen de los bienes o activos producidos. Por lo que los actos ulteriores de conversión, transferencia, transporte, etc., efectuados sobre dichos rendimientos económicos (conociéndose o debiendo presumirse su origen delictivo, con el objeto de evitar la identificación de su origen delictivo, su incautación o decomiso) cumplen, sin mayores cuestionamientos, la tipicidad del delito de lavado de activos.

En segundo lugar, en oposición a los referidos delitos previos (que generan incremento patrimonial con la entrada de los activos en la esfera de dominio del autor), existen también delitos económicamente rentables que se efectúan sobre activos lícitos ya previamente incluidos (con antelación la comisión delictiva) en la propia esfera lícita de dominio patrimonial. La represión en estos últimos casos se fundamenta en el incumplimiento -mediante diferenciadas modalidades de conducta típica- del deber de disposición patrimonial al que el autor se encuentra jurídico penalmente obligado.

Esta categoría de delitos precedentes al blanqueo se manifiesta, con respecto al CP peruano, en los delitos de apropiación ilícita ${ }^{279}$ (art. 190), peculado (art. 387280), malversación de fondos (art. 389281), rehu-

279 Art. 190 (Apropiación ilícita): "El que, en su provecho o de un tercero, se apropia indebidamente de un bien mueble, una suma de dinero o un valor que ha recibido en depósito, comisión, administración u otro título semejante que produzca obligación de entregar, devolver, o hacer un uso determinado, será reprimido con pena privativa de libertad no menor de 2 ni mayor de 4 años...”.

280 Art. 387 (Peculado): "El funcionario o servidor público que se apropia o utiliza, en cualquier forma, para sí o para otro, caudales o efectos cuya percepción, administración o custodia le estén confiados por razón de su cargo, será reprimido con pena privativa de libertad no menor de 4 ni mayor de 8 años...”.

281 Art. 389 (Malversación de fondos): "El funcionario o servidor público que da al dinero o bienes que administra una aplicación definitiva diferente de aquella a los que están destinados, afectando el servicio o la función encomendada, será reprimido con pena privativa de libertad no menor de 1 ni mayor de 4 años... Si el dinero o bienes que administra corresponden a programas de apoyo social, de desarrollo o asistenciales y son destinados a una aplicación definitiva diferente, afectando el servicio o la función encomendada, la pena privativa de libertad será no menor de 3 ni mayor de 8 años...". 
samiento a la entrega de bienes (art. $391^{282}$ ) y en el delito de administración fraudulenta del patrimonio de la persona jurídica (art. 198, inc. ${ }^{283}$ ). Este tipo de estructura delictiva se presenta también en el CP español -además de similares delitos a los aludidos-, con relación al delito de alzamiento de bienes (art. 257, inc. 1284). En todos estos casos, los bienes, activos o ganancias tienen un origen lícito y, antes de la comisión delictiva, se encuentran legalmente incorporados (bajo diferentes títulos o poderes de dominio) el interior de la esfera de dominio patrimonial del agente. Por ello, en la medida que pueda identificarse razonablemente al objeto material (dinero, bienes, efectos o ganancias) -a fin de resolver la controversia probatoria de dicha identificación como de su razonabilidad- es, según nuestro criterio, indiscutible que en todos estos supuestos delictivos nos encontramos frente a delitos previos que pueden dar base al delito de lavado de activos.

El carácter legal de los bienes, sobre los cuales -con posterioridad-se efectúan los actos típicos (del delito previo), constituye un elemento común reconocido en la estructura legal de todos los tipos penales citados. El hecho que los activos o bienes sean entregados en "depósito, comisión, administración u otro título semejante" (art. 190), sean confiados al funcionario o servidor público en "percepción, administración o custodia" (art. 387), en "administración" (art. 389) o "depositados o puestos bajo su custodia o administración" (art. 391), entraña un reconocimiento implícito, pero evidente, de que existe el traslado legal de un título de dominio lícito sobre los bienes. Por ello, la legalidad de los bienes se pone de manifiesto mediante la transfe-

282 Art. 391 (Rehusamiento a la entrega de bienes): "El funcionario o servidor público que, requerido con las formalidades de ley por la autoridad competente, rehúsa entregar dinero, cosas o efectos depositados o puestos bajo su custodia o administración, será reprimido con pena privativa de libertad no mayor de 2 años".

283 Art. 198 (Administración fraudulenta): "Será reprimido con pena privativa de libertad no menor de 1 ni mayor de 4 años el que ejerciendo funciones de administración o representación de una persona jurídica, realiza, en perjuicio de ella o de terceros, cualquiera de los actos siguientes: [...] 8) usar en provecho propio, o de otro, el patrimonio de la persona jurídica”.

284 Art. 257 (Alzamiento de bienes): “1) Será castigado con las penas de prisión de 1 a 4 años...: [...] $1^{\circ}$. El que se alce con sus bienes en perjuicio de sus acreedores. $2^{\circ}$. Quien con el mismo fin realice cualquier acto de disposición patrimonial o generador de obligaciones que dilate, dificulte o impida la eficacia de un embargo o de un procedimiento ejecutivo o de apremio, judicial, extrajudicial o administrativo, iniciado o de previsible iniciación". 
rencia lícita, al autor, del ejercicio de alguno de los poderes reales o títulos de dominio referidos.

En esta segunda tipología de delitos fuente el cambio de estatus jurídico penal del objeto material (esto es, la transformación de un bien "de origen legal" a otro -activo- "maculado" por el delito) tiene por fundamento el incumplimiento de los deberes de disposición patrimonial al que se está jurídico penalmente obligado, en condición de depositario, comisionista, administrador o custodio del patrimonio (privado o público). Las conductas típicas que expresan el incumplimiento de los deberes jurídico penales referidos, son los actos de "apropiación" (art. 190), de "apropiarse o utilizar" (art. 387), "dar una aplicación definitiva diferente" (art. 389), "rehusarse a entregar" (art. 391), "usar en provecho propio" (art. 198, inc. 8), y el de "alzarse” (art. 257, inc. 1 CP español) ${ }^{285}$.

En esta manifestación de delitos previos los bienes, antes de su contaminación delictiva, se caracterizan -según lo previsto en los citados tipos penales- por dos elementos comunes. En primer lugar, la licitud del título que origina los activos. Y, en segundo, que los bienes se encuentran, con antelación a la realización del delito previo, dentro de la esfera lícita de dominio patrimonial de sus autores.

En suma, el que los bienes se encuentren ya en posesión del autor (u otro título de dominio o de administración) antes de la comisión del delito precedente, y que tengan origen lícito, no impide que puedan dar lugar al lavado de activos. En estos supuestos la contaminación delictuosa de los bienes se producirá por efecto de la comisión del delito precedente. El estatus de "licitud" de los bienes o del título de dominio sobre los mismos se perderá (produciéndose la contaminación delictiva), cuando estos se convierten en "efectos" de alguno de los citados delitos (de apropiación ilícita, peculado, malversación

285 Sobre esta cuestión, José Luis Serrano observa que "lo que se predica del delito fiscal también se podría de los delitos socioeconómicos. Así, p. ej., en el alzamiento de bienes o el abuso de información privilegiada los activos previos se sustraen a los acreedores, o los activos procedentes de la negociación bursátil, proceden de actividades lícitas. Y, sin embargo, no cabe negar el origen delictivo de las ganancias obtenidas a consecuencias de conductas defraudatorias”, Cfr. Serrano González De Murillo, J. L. (2013), Delito fiscal y bienes.... 81-82. Comparten, en España, esta constatación Blanco Cordero, I. (2011), El delito fiscal como actividad delictiva previa.... 23-24. Así también, en el Perú, Caro Coria, C. (2015), Lavado de activos provenientes.... 156. 
de fondos, rehusamiento a la entrega de bienes, administración fraudulenta o alzamiento de bienes). Nada impide que los activos, en la medida que sean debidamente identificados y su cuantía pueda ser razonablemente determinada, constituyan bienes idóneos o susceptibles de dar base al delito de lavado. Los actos de conversión, transferencia, ocultamiento, tenencia o transporte de dichos bienes, para evitar la identificación de su origen delictivo, cumplirán la tipicidad objetiva de este delito.

Entre los delitos previos caracterizados tanto por la licitud original de los bienes, como por encontrarse en posesión del autor antes de la comisión del hecho delictivo, tenemos al "delito de defraudación tributaria" (llamado también como defraudación fiscal o fraude al fisco). Este delito se singulariza por la realización de actos fraudulentos que se efectúan sobre activos de origen legal (en efecto -como reconoce la opinión que contradecimos-, con fuente en actividades económicas, mercantiles u otras), que se encuentran ya en la propia esfera de dominio patrimonial del defraudador fiscal, antes de la realización delictiva de este tipo penal tributario. En el delito de defraudación tributaria se reprimen las maniobras fraudulentas (del obligado tributario o por terceros, bajo su dominio) efectuadas en incumplimiento del deber de realizar un desprendimiento patrimonial concreto: la no entrega fraudulenta (total o parcial) de la cuota tributaria defraudada que le corresponde al órgano recaudador del tributo. El impago (total o parcial) del tributo, para tener naturaleza delictiva -y no solo administrativa-, debe realizarse mediante el empleo de maniobras defraudatorias, conforme lo exige el art. 1 de la Ley Penal Tributaria peruana. Este "no pagar fraudulento" 286 se expresa en la evitación de un desembolso por parte del obligado tributario en perjuicio de la administración tributaria.

\section{CONCLUSIONES}

En conclusión, en esta investigación consideramos que el delito de defraudación tributaria -o delito de impago (total o parcial) de la cuota tributaria mediante maniobras defraudatorias- constituye al igual que los delitos de apropiación ilícita, peculado, malversación de fondos, rehusamiento a la entrega de bienes, administración frau-

286 Abanto Vásquez, M. (2000), Derecho penal económico. Parte Especial, Lima, Idemsa. 433 . 
dulenta y alzamiento de bienes ${ }^{287}$, un tipo delictivo idóneo para dar base al delito lavado de activos. Su estructura legal permite constatar que se trata de un delito -como los otros referidos- en el que sus intervinientes efectúan comportamientos (maniobras fraudulentas) dirigidos a evitar ilegalmente el desprendimiento patrimonial de aquellos bienes que ya se encuentran, con antelación al delito fiscal, dentro de su esfera de dominio patrimonial (la cuota tributaria) en perjuicio de su legítimo propietario (la administración tributaria). Por lo tanto, según sostenemos no existe inconveniente dogmático para considerar que la defraudación tributaria, al igual que los otros tipos delictivos citados (que presentan la misma estructura típica), constituye un delito con aptitud para configurarse en actividad criminal previa al delito de lavado de activos.

Una cuestión distinta a la viabilidad dogmática de admitir que la defraudación tributaria pueda configurarse en delito fuente, será la individualización razonable de los bienes (maculados delictivamente) dentro del patrimonio del autor -de los presuntos delitos de defraudación fiscal y de blanqueo de bienes-. El problema principal no radica en la procedencia delictiva de los activos en estos casos (hemos argumentado las razones de por qué la cuota tributaria defraudada sí constituye objeto material idóneo del delito de lavado), sino - como ha puesto de relieve la doctrina- en la dificultad de individualizarlos o independizarlos con respecto al resto del patrimonio del obligado tributario que ha cometido la defraudación fiscal ${ }^{288}$ (y el ulterior blanqueo).

Sin embargo, el que exista dicho problema de contenido probatorio, no exime de considerar - conforme sostenemos- como "típico" al lavado de activos procedentes de la defraudación tributaria. En tal sentido, la dificultad de individualizar dentro del patrimonio del autor la parte que corresponde al egreso no realizado como consecuencia del delito, no enerva la configuración y viabilidad dogmática de la tipicidad del lavado procedente de la defraudación fiscal. No debe entremezclarse dos cuestiones distintas: la tipicidad de un comportamiento con la prueba de la tipicidad. En este caso, de la dificultad probatoria existente -aunque no privativa del delito de defraudación tributaria como delito fuente-, no puede concluirse la ausencia de tipicidad. Salvo que se proponga -de forma equívoca según nuestro entender- que existe falta de tipicidad en todos los casos donde exista el inconveniente de individualización

287 Martínez-Arrieta Márquez de Prado, I. (2014), El autoblanqueo.... 81-82.

288 Blanco Cordero, I. (2015), El delito de blanqueo.... 512. 
razonable de los activos con relación al patrimonio lícito (como ocurre en los tan frecuentes supuestos de "mezcla" de rendimientos de origen delictivo y legal). En estos supuestos no es que no exista tipicidad, sino la presencia de dificultades probatorias, que no es lo mismo.

La problemática de la identificación razonable de los activos maculados, su indivualización y distanciamiento, de aquella parte del patrimonio del autor que tiene contenido legal, no es privativa del delito de defraudación tributaria. Idénticos problemas, y en su misma dimensión, se presentan en todos los delitos provechosos caracterizados por producir "causalmente" rendimientos económicos capaces de ingresar en la esfera de dominio patrimonial del propio autor. Esto es, la dificulta de identificar los activos maculados con respecto al patrimonio lícito se produce en los casos, tan frecuentes, de mezclas de activos legales y delictivos. Hecho que se presenta, inclusive, en los delitos tributarios incuestionablemente calificados como "delitos previos" por el sector doctrinal (objeto de nuestros cuestionamientos) que considera como "inidónea" a la defraudación tributaria para dar base al blanqueo.

Es cuando menos atentatorio al derecho de propiedad ${ }^{289}$ considerar como "contaminado" el íntegro del patrimonio del autor de la defraudación tributaria, pues ello implicaría la arbitraria consideración de que también los activos de origen no delictivo (por estar mezclados los bienes lícitos con los delictuosos) fueren blanqueables. Adicionalmente, infringe el derecho a la defensa procesal que la acusación, o condena por lavado de activos, sean decididas sin haberse probado o determinado razonablemente el alcance de la contaminación delictiva. Esta exigencia puede cumplirse dentro del propio proceso penal por blanqueo de bienes, como fuera de aquel, en aquellos casos donde el delito precedente fue objeto de sentencia (en un proceso penal previo o paralelo).

Asimismo, uno de los argumentos dirigidos por quienes consideran que el delito de defraudación fiscal sería un tipo delictivo inidóneo (para dar base al blanqueo), plantea que en "la defraudación tributaria, precisamente, el individuo no obtiene nada que antes no tuviera". Esto es, que no se verificaría el presuntamente "exigible" nexo causal entre el delito previo y las ganancias que este produciría. Del mismo modo, según matiza otra opinión, dicho delito no causaría un despla-

289 Ambos, K. (2015), La defraudación tributaria como hecho previo.... 303-304. 
zamiento patrimonial de los activos delictuosamente producidos hacia la esfera de dominio del autor (del lavado).

Conforme hemos argumentado, los actos constitutivos del delito de blanqueo, se pueden realizar sobre activos que derivan de dos tipologías de delitos que -aunque presentan elementos estructurales que difieren entre sí-, tienen en común, en primer término, permitir que sus autores logren cuantiosos rendimientos económicos y, luego, vincularse con la criminalidad organizada. (aquellos "delitos que "producen» enriquecimiento con la entrada de los bienes al patrimonio", en contraposición de los "delitos efectuados por «incumplimiento del deber jurídico penal de disposición patrimonial»"). Según la lógica de la posición objetada, con el delito de defraudación tributaria no se obtiene $\mathrm{n}$ activos que no se encontraran ya previamente en el patrimonio de su autor (esto es, que el individuo no obtiene nada que no tuviere antes).

Sin embargo, debemos precisar -siguiendo dicho razonamientoque tampoco el autor obtendría nada que antes no estuviere en su esfera (lícita) de dominio patrimonial en los delitos de peculado, malversación de fondos, rehusamiento a la entrega de bienes (por parte de funcionarios), como tampoco en la apropiación ilícita, la administración fraudulenta del patrimonio de la persona jurídica o el alzamiento de bienes. Por tanto, salvo que se quiera -de modo indebido, a nuestro juicio- proponer que los delitos provechosos tan graves como los referidos (caracterizados por permitir a sus autores obtener sumas cuantiosas de dinero o bienes), no puedan dar lugar al delito de lavado de activos en caso que los provechos delictivamente logrados sean transferidos, convertidos, transportados (u otros). Desde nuestra perspectiva, un enfoque de tal naturaleza motiva espacios importantes de impunidad que deben ser rechazados, no por argumentos basados en lo "político criminalmente insatisfactorio" (que, en muchas ocasiones, va más allá del derecho vigente). Sino porque, desde desde un análisis dogmático de los diversos "delitos provechosos" -existentes en nuestros Códigos Penales-, es admisible identificar que también pueden dar lugar delito de lavado de activos aquellos que delitos efectuados por "incumplimiento del deber jurídico penal de disposición patrimonial". Entre estos -además de los citados-, se encuentra el delito de defraudación fiscal, cuyo fundamento de represión se basa en incumplir (como obligado tributario) mediante actos fraudulentos, el deber de realizar el desplazamiento patrimonial de activos concretos (la cuota tributaria) en favor de su legítimo titular (el órgano recaudador del tributo). 


\section{REFERENCIAS BIBLIOGRÁFICAS}

Abanto Vásquez, M. (2000). Derecho penal económico. Parte Especial, Lima, Idemsa. 433.

Abel Souto, M. (2005). El delito de blanqueo de capitales, Barcelona, Bosch. 224;

Alpaca Pérez, A. (2016). Delincuencia organizada, delitos tributarios y lavado de activos, en Zúñiga Rodríguez, L. (dira) / Mendoza Llamacponcca, F. (coord.), Ley contra el Crimen organizado (Ley No 30077 ). Aspectos sustantivos, procesales y de ejecución penal, Lima, Instituto Pacífico. 631.

Ambos, K. (2015). La defraudación tributaria como hecho previo del lavado de dinero en Alemania Lima, Jurista Editores. 288-315.

Aránguez Sánchez, C. (2000). El delito de blanqueo de capitales, Madrid, Marcial Pons. 187

Aránguez Sánchez, C. y Alarcón Navío, E. (2003). El Código penal francés. Traducido y anotado, Granada, Comares. 181.

Bacigalupo Zapater, E. (2012). Sobre el concurso de delito fiscal y blanqueo de dinero, Civitas, Editorial Civitas. 35-36;

Bitencourt, C. R. y De Oliveira Monteiro, L. (2013). Lavagem de dinheiro segundo a legislação, en RBCCrim, Año 21, Vol. 102, maio-junho, São Paulo, Dos Tribunais Ltda. 185-186.

Blanco Cordero, I. (2011). El delito fiscal como actividad delictiva previa del blanqueo de capitales, en Revista Electrónica de Ciencia Penal y Criminología (RECPC), No 13-1, Universidad de Granada. 20-24;

Blanco Cordero, I. (2015). El delito de blanqueo de capitales, $5^{\mathrm{a}}$ ed., Navarra, Aranzadi. 468.

Borinsky, M. (2014). Fraude fiscal. Un estudio histórico, comparado, de derecho penal, tributario, económico y sociológico, Buenos Aires, Ediciones Didot. 425. 
Buratti, B. y Campana, G. (2012). Contrasto al riciclaggio e misure anti evasione. Le nuove limitazioni alla circolazione dei capitali, San Marino, Maggioli Editore. 51.

Campos Navas, D. (2005). Lavado de dinero y delito fiscal. Posibilidad de que delito fiscal sea el delito precedente al de blanqueo, en La Ley: Revista jurídica española de doctrina, jurisprudencia y bibliografía, $\mathrm{N}^{\circ}$ 5, Madrid, La Ley. 1405.

Caro Coria, C. (2015). Lavado de activos provenientes del delito tributario, en Ambos, Kai / Caro Coria, Carlos / Malarino, Ezequiel (coords.), Lavado de activos y compliance. Perspectiva internacional y derecho comparado, Lima, Jurista Editores. 155-156.

Caro Coria, C., Reyna Alfaro. L. M. y Reátegui Sánchez, J. (2016). Derecho Penal Económico, Tomo II, Lima, Jurista Editores. 663.

Carrión Morillo, D. (2015). Una aproximación a los problemas actuales del blanqueo de capitales y el delito fiscal, en $R E J, 2^{\mathrm{a}}$ época, $\mathrm{N}^{\mathrm{o}}$ 15, UJ. 13.

Cassani, U. (2013). L'infraction fiscale comme crime sous-jacent au blanchiment d'argent: considérations de lege ferenda, en RSDAMF, Vol. 85, No 2, Zürich, Schulthess Verlag. 18.

Codigo Penal alemán

Codigo Penal argentino

Codigo Penal belga

Codigo Penal italiano

Codigo Penal peruano

Codigo Penal portugués

Codigo Penal suizo,

Código Tributario chileno. 
Consejo General del Poder Judicial (2009). Informe al Anteproyecto de Ley de Prevención del Blanqueo de capitales y de la Financiación del terrorismo, del 29 de setiembre, Madrid. 63.

Córdoba Roda, J. (2006). Abogacía, secreto profesional y blanqueo de capitales, Madrid, Marcial Pons. 63;

Córdoba, F. (2015). Delito de lavado de dinero, Buenos Aires, Hammurabi. 187.

Chico de la Cámara, P. (2012). El delito de defraudación tributaria tras la reforma del Código penal por la LO 5/2010, Navarra, Aranzadi. 172-173;

Choclán Montalvo, J. A. (2011). La aplicación práctica del delito fiscal: Cuestiones y soluciones. Adaptado a la Reforma penal de la L.O. 5/2010, Barcelona, Bosch. 338-339;

De acuerdo con el art. 4, lit. a, de la Ley Penal Tributaria (DLeg $\mathrm{N}^{\circ}$ 813, del 19/Abr/1996): La defraudación tributaria será reprimida con pena privativa de libertad no menor de 8 ni mayor de 12 años... cuando:

Del Rosal Blasco, B. (2013). Delito fiscal y blanqueo de capitales: perspectivas ante la nueva reforma del tipo básico del delito fiscal, en Diario La Ley. Sección Doctrina, Año XXXIV, No 8017, de 6 de febrero, Ref. D-45, Madrid, Editorial La Ley. 5.

Díaz y García Conlledo, M. (2014). ¿Puede el delito de defraudación tributaria constituir actividad delictiva previa a efectos del blanqueo?, en DEMETRIO CRESPO, Eduardo (dir.) / MAROTO CALATAYUD, Manuel (coord.), Crisis financiera y derecho penal económico, Montevideo, BdF. 614.

Díaz, V. (2012). La exégesis del delito de lavado de dinero y la desvinculación con el delito fiscal, en Bertazza, H. / D’Álbora, F. (dirs.), Tratado de lavado de activos y financiación del terrorismo. Prevención, investigación y represión, Tomo I, Buenos Aires, La Ley. 290.

Dópico Gómez-Aller, J. (2010). Si todo es blanqueo, nada es blanqueo, en LegalToday.com, del 15 de enero, Madrid. 1. 
Durrieu Figueroa, R. (2013). El delito tributario y el lavado de activos, en Alterini, J. (dir.), La Ley, Año LXXVII, No 87, 14 de mayo, Buenos Aires. 1.En: http://www.fatf-gafi.org/media/fatf/documents/ recommendations/pdfs/FATF-40-Rec-2012-Spanish.pdf

Fernández Junquera, M. (2012). Defraudación fiscal, blanqueo de capitales y regularización tributaria, en $R E D F$, No 155 , julio-setiembre, Navarra, Aranzadi. 33;

Fernández Teruelo, J. (2010). Capítulo 14: Blanqueo de capitales, en Ortiz de Urbina Gimeno, Íñigo (coord.), Memento Experto. Reforma penal 2010. Ley orgánica 5/2010, Madrid, Ediciones Francis Lefebvre. 325 .

Financial Action Task Force (2010). Consultation Paper. The Review of the Standards - Preparation for the 4th Round of Mutual Evaluations, October 2010, GAFI/OECD. 3. Disponible en: http://www.fatf-gafi. $\mathrm{org} / \mathrm{media} /$ fatf/documents/publicconsultation/First\%20public\%20 consultation\%20document.pdf

Financial Action Task Force (2011). Consultation Paper. The Review of the Standards - Preparation for the 4th Round of Mutual Evaluations. Second public consultation, June 2011, GAFI/OECD. 4. Disponible en: http://www.fatf-gafi.org/media/fatf/documents/publicconsultation/ Second\%20public\%20consultation\%20document.pdf

Fiscal General del Estado (2009). Informe del Consejo Fiscal sobre el Anteproyecto de Ley de Prevención del Blanqueo de capitales y de la Financiación del terrorismo, del 28 de setiembre, Madrid. 4.

Galain Palermo, P. (2015). Lavado de activos en Uruguay: Una visión criminológica, en Ambos, K., Caro Coria, C. y Malarino, E. (coords.), Lavado de activos y compliance, Lima, Jurista Editores. 334.

Gálvez Villegas, T. (2009). El delito de lavado de activos. Criterios sustantivos y procesales. Análisis de la Ley No 27765, Lima, Jurista Editores. 86.

Gálvez Villegas, T. (2014). El delito de lavado de activos, Lima, Instituto Pacífico. 104 
García Bañuelos, J. A. (2015). El delito fiscal como actividad delictiva previa del delito de blanqueo de capitales, en QF, No 1-2, Navarra, Aranzadi. 107-109.

García Cavero, P. (2015). El delito de lavado de activos, Lima, Jurista Editores. 121-122.

Gómez Benítez, J. M. (2007). Reflexiones técnicas y de política criminal sobre el delito de blanqueo de bienes en Cuadernos de Politica Criminal, no 91. 5-26

Hinostroza Pariachi, C. (2009). El delito de lavado de activos, Lima, Grijley. 179-180.

Luzón Campos, E. (2012). Blanqueo de cuotas defraudadas y la paradoja McFly, en Diario La Ley, Sección Tribuna, No 7818, Año XXXIII, del 14 de marzo, Ref. D-120, Madrid, Editorial La Ley. 2.

Mallada Fernández, C. (2012). Blanqueo de capitales y evasión fiscal, Valladolid, Lex Nova. 174-176.

Manjón-Cabeza Olmeda, A. (2012). Un matrimonio de conveniencia: blanqueo de capitales y delito fiscal, en RDP, Año XII, No 37, Valladolid, Lex Nova. 37.

Martín Queralt, J. B. (2014). Delito fiscal y blanqueo de capitales, en García Prats, A. (dir.), Intercambio de información, blanqueo de capitales $y$ lucha contra el fraude fiscal, Madrid, IEF. 33.

Martínez-Arrieta Márquez de Prado, I. (2014). El autoblanqueo. El delito fiscal como delito antecedente del blanqueo de capitales, Valencia, Tirant lo Blanch. 22.

Palma Herrera, J. M. (2000). Los delitos de blanqueo de capitales, Madrid, Edersa. 274.

Quintero Olivares, G. (2006). El delito fiscal y el ámbito material del delito de blanqueo, en $A J A, \mathrm{~N}^{\circ}$ 698, del 17 de abril, Navarra, Aranzadi. 1. 
Reque Mata, Susana (2009). ¿Puede considerarse el delito fiscal delito previo al delito de blanqueo de capitales?, en I Congreso de prevención y represión del blanqueo de dinero, Valencia, Tirant lo Blanch. 287.

Sánchez Huete, M. A. (2016). La Administración Tributaria ante el delito. La nueva regularización voluntaria, en QF, $\mathrm{N}^{\circ} 7$, abril, Navarra, Aranzadi. 39.

Sánchez Stewart, N. (2014). La declaración tributaria especial y el blanqueo de capitales, en REDS, $N^{\circ} 4$, enero-junio, 2014, Madrid, Dykinson. 6.

Sentencia de Casación No 07-82977 (del 20/Feb/2008), emitida por la Sala Penal del Tribunal de Casación de Francia. Casación dirigida contra la resolución condenatoria emitida por el Tribunal de Apelación de Aix-en-Provence (del 28/Mar/2007). Disponible en: https:// www.legifrance.gouv.fr/affichJuriJudi.do?oldAction=rechJuriJudi\&idTexte=JURITEXT000018338279\&fastReqId=748356780\&fastPos $=1$

Sentencia de Casación No 6061/2012 (del 17/Ene/2012, FJ 3), emitida por la Sección Segunda de la Sala Penal del Tribunal Supremo de Italia. Disponible en: http://www.italgiure.giustizia.it/xway/application/nif/clean/hc.dll?verbo=attach $\& \mathrm{db}=$ snpen $\&$ id $=. / 20120217 /$ snpen@s20@a2012@n06061@tS.clean.pdf

Serrano González De Murillo, J. L. (2013). Delito fiscal y bienes con origen en actividad delictiva como objeto de blanqueo, en Cuadernos de Política Criminal, No 111, Año III, Madrid, Dykinson. 83-84. 
Recibido: 04/12/2017

Aprobado: 25/05/2018

Dr. Fidel Nicolás Mendoza Llamacponcca, PhD: Abogado por la UNMSM. Máster y Doctor en derecho por la Universidad de Salamanca. Ha sido becario de investigación en el Seminario de Derecho Penal de la Universidad de Friburgo - Suiza (2010), a cargo del prestigioso Profesor Dr. h.c. mult. José Hurtado Pozo. En el marco de su formación en Derecho Penal ha seguido cursos sobre "lucha contra la corrupción internacional" en la Universidad de Ginebra (Suiza), Criminalidad organizada transnacional (Sevilla), Prevención y represión del lavado de activos y Técnicas de litigación oral con el Nuevo Código Procesal Penal (Perú). Ha sido profesor universitario y conferencista en diversos temas de derecho penal económico y derecho procesal penal.

Correo electrónico: fidel_mendoza21@hotmail.com 